\title{
Distribution characteristics of microplastics in the soil of mangrove restoration wetland and the effects of microplastics on soil characteristics
}

\author{
Bo Hu \\ Huaqiao University College of Chemical Engineering \\ Peiyong Guo ( $\sim$ peiyongguo@163.com ) \\ Huaqiao University - Xiamen Campus \\ Siyu Han \\ Huaqiao University College of Chemical Engineering \\ Yifan Jin \\ Huaqiao University College of Chemical Engineering \\ Yiting Nan \\ Huaqiao University College of Chemical Engineering \\ Jun Deng \\ Huaqiao University College of Chemical Engineering \\ Junming He \\ Huaqiao University College of Chemical Engineering \\ Yaqing Wu \\ Huaqiao University \\ Sijia Chen \\ Huaqiao University College of Chemical Engineering
}

\section{Research Article}

Keywords: Microplastics, Wetland soil, Polyethylene terephthalate, Soil physicochemical properties, Abundance

Posted Date: January 13th, 2022

DOI: https://doi.org/10.21203/rs.3.rs-1185534/v1

License: (c) (i) This work is licensed under a Creative Commons Attribution 4.0 International License. Read Full License 


\section{Abstract}

Microplastics that enter the soil environment are transformed by migration and can affect soil properties, which in turn have an impact on soil function and biodiversity. In this study, we investigated the distribution of soil microplastics at different planting densities and their effects on soil properties in a mangrove restoration wetland. The results showed that the average abundance of soil microplastics in the study area was 2177.5 $\mathrm{n} / 500 \mathrm{~g}$, with the largest proportion of $0.038-0.05 \mathrm{~mm}$ diameter microplastics accounting for $70.9 \%$ and the rest of the diameter microplastics accounting for less than $20 \%$, indicating that the smaller the diameter microplastics are easy to accumulate in the wetland soil. The abundance of microplastics in the restored area by planting density was ranked as $0.5 \times 0.5 \mathrm{~m}>1.0 \times 0.5 \mathrm{~m}>1.0 \times 1.0 \mathrm{~m}>$ control area. Three microplastics, polyethylene terephthalate (PET, accounted for $52 \%$ ), polyethylene (PE, accounted for $24 \%$ ), and polypropylene (PP, accounted for $15 \%$ ), were the most prevalent and dominant microplastics in the soils of the area. SEM images showed that fractures, tears, EDS spectroscopy showed that a large number of metals were detected on the surface of microplastics. PET can influence the distribution of soil particle size due to its adsorptive viscosity, which may affect soil structure. Apart from soil pH, all other physicochemical factors changed significantly in response to PET. Besides, the results of the $\mathrm{CV}$ analysis reflect that soils in vegetated areas are more susceptible to the effects of PET than bare ground soils resulting in greater variability in the properties.

\section{Introduction}

Microplastics can be widely detected in marine, freshwater, and wetland soils (Cesa et al., 2017), indicating that microplastics have a high capacity for transport and dispersal (Cincinelli et al., 2017; Jiang et al., 2019). In particular, wetlands are uniquely located between terrestrial and aquatic ecosystems, with alternating hydrodynamic conditions, nutrient-rich sediment substrates, dense aquatic vegetation, and high biodiversity (Karstens et al., 2015; Langan et al., 2018), creating favorable conditions for the enrichment and transport of microplastics, and wetlands have become important hubs for microplastic transport in global ecosystems (Liu et al., 2019b). In particular, coastal wetlands are one of the aggregation sites for the conversion of plastic macro-debris into micro-debris (Yao et al., 2019). Besides, microorganisms can grow adsorbed on the surface of microplastics and interact with organic compounds in the environment, all of which can influence their fate in and on wetland environments (Hossain et al., 2018; Liu et al., 2019c), so it is important to study the interaction between soil and microplastics in coastal estuarine wetlands.

In coastal wetland environments, external forces such as mechanical erosion, chemical and biological processes can affect the surface morphology of microplastics to change, and their rough or cracked texture is typical evidence of microplastic degradation and can show the degree of aging and surface adsorption of microplastics (Veerasingam et al., 2016; Zhou et al., 2018).Qin et al (Qin et al., 2020) studied the contamination of microplastics in the sediments of the Ulansu Sea, and observed by SEM that the surface of microplastics there were cracks, pores, and irregular curl, and these microplastics may provide attachment sites for other contaminants. Concerning elemental attachment on the surface of microplastics, Mehdinia et al (Mehdinia et al., 2020) identified and analyzed microplastics in coastal sediments from the southern Caspian Sea in northern Iran, and examined the elemental attachment on the surface of microplastics using SEM/EDS, indicating that microplastics can adsorb metal elements.

Microplastics in wetland environments are mainly derived from nearby human activities. Garcés-Ordóñez et al. (Garces-Ordonez et al., 2019) sampled microplastics in mangrove wetland soils near and away from population centers in the Colombian Caribbean and found that the abundance of microplastics increased the closer the population centers were. Besides, microplastics from human activities can enter the mangrove wetland environment and accumulate in wetland soils through effluent discharge (Naji et al., 2019; Wang et al., 2020). Edo et al (Edo et al., 2020) found by comparing the abundance of plastic particles in several natural and lagoonal wetlands that the amount of plastic entering the lagoonal wetlands was 40 times higher than that of the natural wetlands. Plastic waste from aquaculture is also a significant source of microplastics in wetlands. For example, microplastics in the mangrove wetlands of Qinzhou Bay originate from the decomposition of polystyrene foam buoys, plastic woven bags, and fishing nets from nearby farms (Li et al., 2018). Tidal or wave-induced plastic decomposition and precipitation-induced surface runoff are also important processes that carry microplastics into wetland ecosystems. Mohamed et al (Nor and Obbard, 2014) found that microplastics in intertidal mangrove wetlands in Singapore may come from the degradation of marine plastic debris accumulated in mangroves, and four types of polymers were identified, including polyethylene, polypropylene, nylon, and polyvinyl chloride.

It has been shown that microplastics can combine with soil to form a variety of agglomerates: shredded plastics form loose agglomerates and plastic fibers form denser agglomerates (Rillig et al., 2017; Wong et al., 2020). Zhang et al (Zhang et al., 2019) found that polyester resin microfibres can occupy pore spaces of $<30 \mu \mathrm{m}$ or can mix with soil particles to form soil clods with large pores ( $>30 \mu \mathrm{m})$. Besides, microplastics can affect the soil-water cycle and thus alter the water infiltration capacity of the soil, thereby affecting soil water evaporation and the migration of contaminants along with fractures to deeper soils (Boots et al., 2019) (Hueffer et al., 2019). Soil enzymes are closely related to a variety of soil biochemical processes and play an important role in regulating soil nutrient cycling, however microplastics also have a significant effect on soil enzyme activity (Hu et al., 2020). Liu et al (Liu et al., 2017) reported that high concentrations of polypropylene microplastics ( 28\%, w/w) greatly increased the nutrient (C, N, P) content of soluble organic matter (DOM). Qi et al (Qi et al., 2020) found significant differences in the effects of different microplastic treatments on soil $\mathrm{pH}$, conductivity and carbon to nitrogen ratio and that the concentration, exposure time and type of

Page $2 / 24$ 
microplastic largely determined their effect on the soil. The above studies show that when microplastics enter the soil environment, due to their small particle size and large specific surface area, their indicated adsorption capacity increases, and when combined with organic matter in the soil, etc., they can significantly alter soil physicochemical properties and material cycling, amounting to daily impacts on soil ecosystem health. Wetlands are considered to be one of the most productive ecosystems and it is important to investigate the effects of microplastics on their soil physicochemical properties.

In this study, we investigated the distribution characteristics of soil microplastics under different planting densities of vegetation in a mangrove restoration wetland in Jinjiang estuary, Fujian Province, and clarified the effects of microplastics (polyethylene terephthalate, PET) on soil properties in a mangrove restoration wetland, intending to provide a scientific basis and reference for research on the environmental behavior and effects of microplastics in estuarine restoration wetlands.

\section{Materials And Methods}

\subsection{Soil and microplastics sample.}

In September 2020, top soil samples were taken from the restored and control areas of the mangrove restoration wetland in the Jinjiang estuary under different planting densities of "Kandelia candel - Rhizophora stylosa - Bruguiera gymnorhiza". The collected soil samples were sealed and labelled in self-sealing bags and transported back to the laboratory for natural air-drying on the same day. A portion of the air-dried soil was analyzed for physical and chemical factors and the results are shown in Table 1.

Table 1

The physicochemical factors of wetland soil.

\begin{tabular}{|c|c|c|c|c|c|c|c|}
\hline & \multicolumn{3}{|c|}{ Particle size } & \multirow[t]{3}{*}{$\mathrm{pH}$} & \multirow{3}{*}{$\begin{array}{l}\text { SOM } \\
\left(\mathrm{g} \cdot \mathrm{kg}^{-1}\right)\end{array}$} & \multirow{3}{*}{$\begin{array}{l}\text { TN } \\
\left(\mathrm{mg} \cdot \mathrm{kg}^{-1}\right)\end{array}$} & \multirow{3}{*}{$\begin{array}{l}\text { TP } \\
\left(\mathrm{mg} \cdot \mathrm{kg}^{-1}\right)\end{array}$} \\
\hline & Clay (\%) & Silt (\%) & Sand (\%) & & & & \\
\hline & $<2 \mu \mathrm{m}$ & $2 \sim 20 \mu \mathrm{m}$ & $>20 \mu \mathrm{m}$ & & & & \\
\hline Control area & 3.45 & 77.49 & 19.06 & 7.49 & 28.71 & 357.49 & 560.64 \\
\hline Recovery area & 5.82 & 74.18 & 20.01 & 6.31 & 37.24 & 985.88 & 1197.25 \\
\hline
\end{tabular}

Based on the study of soil microplastics in this mangrove wetland in 2017 (Deng et al., 2020), polyethylene terephthalate (PET) was found to be the most abundant in the area. For this reason, PET was selected as the microplastic material (Figure 1.a, Analytical grade powder, YounglingTECH Company, Beijing, China) for this study on the effect of microplastics on soil properties. The particle size distribution of the PET powder was examined using a Malvern particle sizer (MASTERSIZER 2000) and the results showed that the particle size of this material was < $700 \mu$, with $8.3 \%$ of the microplastic PET particles having a particle size of $700-355 \mu \mathrm{m}, 31.71 \%$ having a particle size of $355-158 \mu \mathrm{m}, 43.01 \%$ having a particle size of $158-50 \mu \mathrm{m}$, and $16.96 \%$ had particle sizes < $50 \mu \mathrm{m}$ (Figure 1. b). Besides, SEM images of the microplastic powder were obtained using a field emission full scanning electron microscope (Nippon Co., Ltd., Japan) (Figure 1. c-d), which observed that the microplastic had a rough and void surface.

\#Figure 1\#

\subsection{Experimental methods}

\subsubsection{Flotation of soil microplastics under different planting densities}

Microplastics were extracted from soil samples by density separation in saturated $\mathrm{NaCl}$ solution (Amrutha and Warrier, 2020). An unground soil sample of $50 \mathrm{~g}$ was accurately weighed, $250 \mathrm{ml}$ of saturated $\mathrm{NaCl}$ solution was added to it and the mixture was stirred for 10 min with a magnetic stirrer, and the supernatant, including the microplastics, was passed through a grading sieve system consisting of four stainless steel sieves stacked together with different pore sizes (all $10 \mathrm{~cm}$ in diameter, with pore sizes of $2 \mathrm{~mm}, 1 \mathrm{~mm}, 0.5 \mathrm{~mm}$ and $0.038 \mathrm{~mm}$ ), the process was repeated five times to ensure adequate extraction of the microplastics from the soil. The intercepted material was rinsed from the sieve into a clean beaker and left to stand for $24 \mathrm{~h}$ before being filtered through a vacuum extraction device using a $0.45 \mu \mathrm{m}$ pore size glass cellulose membrane, which was then placed in a glass Petri dish. To prevent contamination from external sources, the separation, extraction, and observation of microplastics were carried out in a clean and airtight environment and the Petri dishes with the filter membranes were covered with tin foil.

\subsubsection{Identification and Analysis of Soil Microplastics}

The above-graded separation steps allowed the microplastics in the soil samples to be classified into three classes according to their diameter size: 1-2 mm, 0.5-1 mm, and 0.038-0.5 mm (Peng et al., 2017). Microplastics on the membrane were observed and photographed with an optical 
electron microscope (Olympus SZ61, Japan). Starting from the top and moving in a zigzag pattern from left to right, small squares were observed one after the other to look for microplastics and were visually identified and classified by shape and color according to the same rules as those used by Han et al (Han et al., 2020). The microplastics were classified into the following three shapes: fibrous, spherical and fragmented, as well as seven different colors: clear, blue, black, white, green, red, and orange. In the blue category, dark blue, light blue, and green are included; in the red category, purple and pink particles are also included; and the white category does not include transparent microplastics. A Raman spectrometer (Renishaw inVia, UK), which does not require pre-treatment of the sample, was chosen for this study to identify the microplastic polymer types. A laser equipped with a $785 \mathrm{~nm}$ laser was chosen for the experiments, scanning the spectral range $100-3200 \mathrm{~cm}^{-1}$ (Frere et al., 2016). Each sample was scanned three times under the same conditions, with each scan position being switched randomly to ensure the accuracy of the results. Besides, the morphology of typical microplastics was studied using a scanning electron microscope (Hitachi S4800, Japan) and the elemental composition of the microplastic surface was determined using an energy spectrometer (X-Act, Oxford) (Wang et al., 2017).

\subsubsection{Experimental design of effects of microplastics on soil properties}

Referring to the soil culture method of Liu et al (Liu et al., 2019a), a portion of the pre-treated wetland soil was incubated inappropriately sized beakers (using cling film with eyelets for closure). In this study, the amount of microplastic applied (w/w, 7\% (M1) and 28\% (M2) respectively) was determined according to Lwanga (Lwanga et al., 2016). Our experiment included six treatments: 1 ) ${ }^{a} \mathrm{CK}$ : bare ground soil only; 2 ) ${ }^{\mathrm{a}} \mathrm{M} 1: \mathrm{7} \%$ microplastics + bare ground soil; 3) ${ }^{\mathrm{a}} \mathrm{M} 2$ : $28 \%$ microplastics + bare ground soil; 4) ${ }^{\mathrm{b}} \mathrm{CK}$ : vegetated area soil only; 5) ${ }^{\mathrm{b}} \mathrm{M} 1: 7 \% \mathrm{microplastics} \mathrm{+}$ vegetated area soil; 6) ${ }^{\mathrm{b}} \mathrm{M} 2: 28 \%$ microplastics + vegetated area soil. The soil was slightly compacted using a small manual soil compactor to ensure that it was compacted in all samples. Soil moisture was maintained at $50 \%$ throughout the experiment and each soil sample was incubated in an artificial climate chamber (incubation conditions: light to the dark ratio: 14h:10h, humidity: $80 \%$ ). As the soil was air-dried, a pretreatment of 1 week was required to re-establish microbial metabolism. One sub-soil sample was taken from each pot on days $1,3,7,14$, and 30 after the end of the pre-treatment, with a final collection of 90 sub-samples (6 treatments $\times 3$ replicates $\times 5$ sampling points), which were labeled and preserved. Some of the fresh soil samples treated with PET were used to determine soil ammonium and nitrate nitrogen. Another part of the soil samples was dried naturally, ground in a mortar, sieved through 20 and 100 mesh sieves respectively, and then stored in self-sealing bags for the determination of soil physical and chemical properties.

\subsubsection{Determination of soil properties of microplastics}

The unground soil was digested by $\mathrm{H}_{2} \mathrm{O}_{2}$ and $\mathrm{HCl}$ for more than 12 hours, the supernatant was removed by siphon, and then the precipitation was dispersed with sodium hexametaphosphate. Finally, the soil particle size was determined by a Malvern laser particle size analyzer (Mastersizer 2000$, UK). According to the American soil particle size classification standard, the soil particle size is divided into three grades: clay (< $2 \mu \mathrm{m})$, silt $(2 \sim 20 \mu \mathrm{m})$, and sand (> $20 \mu \mathrm{m})$. pH meter (Sartorius, PB-10, Germany) was used to determine soil pH value. The content of total phosphorus in soil was determined. After the soil was calcined at $450{ }^{\circ} \mathrm{C}$ in a muffle furnace, the soil was moved to a centrifuge tube and $3.5 \mathrm{~mol} / \mathrm{L} \mathrm{HCl}$ was added and shaken for 16 hours. The supernatant was obtained by centrifugation, and the content of total phosphorus in the extract was analyzed by molybdenum blue colorimetry. Soil alkaline phosphatase activity was determined by disodium benzene phosphate colorimetry. After adding $0.5 \mathrm{~mL}$ toluene to a certain amount of soil, $15 \mathrm{~min}$ and then adding a boric acid solution of $6.75 \mathrm{~g} / \mathrm{L}$ disodium benzene phosphate pH=10, shake it well and put it in an incubator at $37^{\circ} \mathrm{C}$. After a certain period, use the boric acid solution of $\mathrm{pH}=9.0,2.5 \%$ potassium ferricyanide, and $0.5 \%$ aminoantipyrine solution. The absorbance was measured at the $570 \mathrm{~nm}$ wavelength. Soil total nitrogen was determined by the potassium persulfate $\left(\mathrm{K}_{2} \mathrm{~S}_{2} \mathrm{O}_{8}\right)$ oxidation method. Oxidant $\left(0.074 \mathrm{~mol} / \mathrm{L} \mathrm{K}_{2} \mathrm{~S}_{2} \mathrm{O}_{8}+0.24 \mathrm{~mol} / \mathrm{L} \mathrm{NaOH}\right)$ was added to the soil and sterilized after $2 \mathrm{~h}$ oscillation. The supernatant was centrifuged and the content of total nitrogen was determined by UV spectrophotometry. The determination methods of ammonium nitrogen and nitrate nitrogen in the soil are extraction-indophenol blue colorimetry and ultraviolet spectrophotometry. Determination of soil ammonium nitrogen: Mix $2 \mathrm{~mol} / \mathrm{L} \mathrm{KCl}$ extract with fresh soil sample and shake on a shaker, filter. The $\mathrm{KCl}$ extract was added again to the filtrate and $2.5 \mathrm{~mL}$ of phenol solution and $2.5 \mathrm{~mL}$ of sodium hypochlorite alkaline solution were added in turn and shaken well. After $1 \mathrm{~h}$ at room temperature, $1 \mathrm{~mL}$ of masking agent was added and the absorbance was finally determined at $625 \mathrm{~nm}$. Determination of soil nitrate nitrogen: $0.01 \mathrm{~mol} / \mathrm{L}$ calcium chloride extract was mixed with fresh soil and shaken, then filtered and acidified by adding $1.00 \mathrm{~mL}$ of $1: 9$ sulphuric acid solution to the filtrate. Finally the absorbance values (A210 and A275) were measured at 210nm and $275 \mathrm{~nm}$ respectively in a I cm optical diameter quartz cuvette.

\subsection{Data analysis}

One-way analysis of variance (ANOVA) was used to analyze the variability in the abundance of soil microplastics at different planting densities and the differences in soil particle size, $\mathrm{pH}$, alkaline phosphatase, total phosphorus, total nitrogen, ammonium nitrogen, and nitrate nitrogen at different microplastic addition concentrations after treatment with microplastics $(p<0.05)$. Pearson correlation was used to analyze the correlation between each soil property. Besides, all experimental data processing and statistical analyses were completed using Excel 2019 and SPSS 25.0, and graphs were drawn using Origin Pro 2020b, PowerPoint 2019, and Word 2019.

\section{Results}

Page $4 / 24$ 


\subsection{Morphology and abundance characteristics of soil microplastics at different planting densities in mangrove restoration wetlands in the Jinjiang River estuary}

\subsubsection{Morphological characteristics of soil microplastics in mangrove restored wetlands}

Microscopic photographs of the different types of microplastic samples are shown in Figure 2. (a) are white lumpy and green lumpy, irregularly shaped and of a certain thickness, and harder than the film. (b) and (c) are blue and red filamentous fibers, respectively, with elongated circumference, which are easier to identify. (d) and (e) are transparent and red films, respectively, which are irregular in shape, have a small thickness but a large area and are easily deformed or bent by light touch with tweezers, etc. (f) Transparent fibers and spherical granules, of which the granules are regular in shape, round, small in diameter and with a glossy surface, are easier to identify. Based on observations under the microscope, this study was carried out to count the abundance of microplastics and to classify the percentage of them by shape and color.

By nature of microplastic appearance (Figure 3. A), strip and granular microplastics were the most represented in this study area, with $45 \%$ and $40.4 \%$ respectively, followed by fragmented microplastics with $13.7 \%$, and films and agglomerated fibers with less than $1 \%$. By the color of microplastics (Figure 3. B), transparent and white microplastics were the largest with $47 \%$ and $38.1 \%$ respectively; all other colors accounted for less than $10 \%$, in order of black (6\%), blue (4.5\%), red $2.1 \%$, yellow $(1.3 \%)$ and green $(1.1 \%)$.

\#Figure 2\#

\#Figure 3\#

\subsubsection{Identification of microplastics by Raman spectroscopy}

In this study, a total of 100 soil microplastics samples were identified by Raman spectroscopy. Through comparative analysis with the standard atlas or the spectra in the existing literature, whether they are microplastics or not was finally determined, as well as the combination of their polymer types. Among the 100 microplastics samples identified and analyzed by Raman spectroscopy, the three kinds of plastics with the largest proportion are: (a) polyethylene terephthalate (PET), accounting for $52 \%$, (b) polyethylene (PE), accounting for $24 \%$, and (c) polypropylene (PP), accounting for $15 \%$. The Raman spectra of these three microplastics are shown in Figure 4.

\#Figure 4\#

\subsubsection{Surface microstructure and elemental composition of microplastics}

Scanning electron microscopy (SEM) was applied to observe the microplastics isolated from the wetland soil, and typical surface characteristics of some of the samples are shown in Figure 5. $(a, b)$ are SEM images of the microplastic films at different magnifications. It can be observed that the surface of the films is relatively flat, but there are obvious holes and folds. (c, d) are SEM images of transparent fibers at different magnifications. The fibers are elongated and their surfaces are rough and have other substances adhering to them. ( $\mathrm{g}, \mathrm{h}$ ) are SEM images of white granular microplastics at different magnifications. Compared to the films and fibers, the granular microplastics have a smooth surface with obvious protrusions and other substances adhering to the surface at the locations of the protrusions. (j, k) are SEM images of the bulk microplastic at different magnifications. The surface of the bulk microplastic is very rough compared to the film and has obvious cracks, fractures, and voids, again with other material adhering to it.

\#Figure 5\#

\subsubsection{Abundance distribution characteristics of soil microplastics at different planting densities in mangrove restored wetlands}

The distribution of soil microplastic abundance at different planting densities in the mangrove restoration wetland is shown in Figure 6 . The soil microplastic abundance for the entire study area ranged from $563.3-6196.7 \mathrm{n} / 500 \mathrm{~g}$ (dry soil) with a mean abundance of $2177.5 \mathrm{n} / 500 \mathrm{~g}$ (dry soil), with the maximum value occurring in the restored area at a planting density of $0.5 \times 0.5$. In the present study, the use of graded sieve separation allowed a direct classification of microplastics into three types by diameter (Figure 6. B). On the one hand, it is clear from the analysis of variance (Figure 6. A) that the abundance of microplastics with diameters of 1-2 mm and 0.5-1 mm, respectively, did not differ significantly ( $p>$ 0.05 ) at different planting densities, whereas the abundance of microplastics at diameters of $0.038-0.5 \mathrm{~mm}$ differed significantly ( $p<0.05)$ and the abundance size of microplastics in the recovery zone at different planting densities was ranked as $0.5 \times 0.5 \mathrm{~m}>1.0 \times 0.5 \mathrm{~m}>1.0 \times 1.0 \mathrm{~m}>$ control zone. On the other hand (Figure 6. B), most of the microplastics in this restoration zone were between 0.038-0.5 mm in diameter, which accounted for $70.9 \%$, and about $15.5 \%$ of the microplastics were between $0.5-1 \mathrm{~mm}$ in diameter, while about $13.6 \%$ of the microplastics were $1-2$ $\mathrm{mm}$ in diameter, indicating that smaller diameter microplastics are more likely to accumulate in the wetland soil. 


\subsection{Effects of microplastics (PET) on soil physical and chemical properties 3.2.1 Effect of PET on the particle size of wetland soil}

Figure 7 shows the changes in the proportion of soil clay, silt, and sand particles in the bare soil and vegetated area of the mangrove restoration wetland after the addition of PET. Table 3.2 shows the results of the statistical analysis of the changes in soil clay, silt, and sand particles. For soil clay particles (Figure 7. A, B), the proportion of clay particles in bare soil treated with ${ }^{\mathrm{a}} \mathrm{M} 1$ (7\% PET) was 5.34-6.39\%, with a low fluctuation overall, but a slowly increasing trend from the 14th day of culture; however, the percentage of clay in bare soil treated with ${ }^{\mathrm{a}} \mathrm{M} 2$ (28\% PET added) was 4.55-6.77\% , with overall fluctuating changes, showing a trend of increasing, then decreasing and then slowly increasing. The clay content of bare soil treated with ${ }^{\mathrm{a}} \mathrm{M} 1$ and ${ }^{\mathrm{a}} \mathrm{M} 2$ was significantly higher than that of ${ }^{\mathrm{a}} \mathrm{CK}(0 \%$ pet) on the 7 th and 14 th day $(\mathrm{p}<0.05$, Table 2$)$. In terms of mean value analysis, the clay content of bare land under ${ }^{\mathrm{a}} \mathrm{M} 1$ and ${ }^{\mathrm{a}} \mathrm{M} 2$ treatments was higher than that of CK group, and the mean value was ${ }^{\mathrm{a}} \mathrm{M} 1$ (5.67\%) > ${ }^{\mathrm{a}} \mathrm{M} 2$ (5.42\%) > ${ }^{\mathrm{a}} \mathrm{CK}$ (5.35\%). However, the proportion of soil clay in vegetation area after PET cultivation was opposite to that in bare soil. From the 3rd day of cultivation, the proportion of soil clay in vegetation area after ${ }^{\mathrm{b}} \mathrm{M} 1$ and ${ }^{\mathrm{b}} \mathrm{M} 2$ treatment showed a significant downward trend. With the seventh day of cultivation, the proportion of soil clay increased, but it was still below ${ }^{\mathrm{b}} \mathrm{CK}$. In addition, the average proportion of clay particles in the vegetation area treated with ${ }^{\mathrm{b}} \mathrm{M} 1$ and ${ }^{\mathrm{b}} \mathrm{M} 2$ and ${ }^{\mathrm{b}} \mathrm{CK}$ group was ${ }^{\mathrm{b}} \mathrm{CK}(6.07 \%)>{ }^{\mathrm{b}} \mathrm{M} 2(5.72)>{ }^{\mathrm{b}} \mathrm{M} 1(5.47)$. Combined with CV (coefficient of variation) analysis, CV- ${ }^{\mathrm{b}} \mathrm{M} 1$ (19.19\%) $\triangle \mathrm{CV}-{ }^{\mathrm{a}} \mathrm{M} 1$ (7.68\%), but CV-b ${ }^{\mathrm{b}} \mathrm{M} 2$ (7.48\%) $\otimes_{\mathrm{CV}}{ }^{\mathrm{a}} \mathrm{M} 2(14.31 \%)$. 
Table 2

Statistical analysis results of soil particle size.

\begin{tabular}{|c|c|c|c|c|c|c|c|}
\hline & Day & ${ }^{\mathrm{a}} \mathrm{CK}$ & aM1 & aM2 & ${ }^{b} \mathrm{CK}$ & bM1 & ${ }^{b} \mathrm{M} 2$ \\
\hline \multirow{9}{*}{$\begin{array}{l}\text { Clay } \\
\%\end{array}$} & 1 & $5.78 \pm 0.23 a$ & $5.34 \pm 0.12 a$ & $4.54 \pm 0.28 b$ & $7.47 \pm 0.15 a$ & $7.3 \pm 0.72 \mathrm{ab}$ & $5.58 \pm 0.38 b$ \\
\hline & 3 & $4.67 \pm 0.26 a$ & $5.45 \pm 0.47 a$ & $4.83 \pm 0.37 a$ & $5.54 \pm 0.1 a$ & $6.11 \pm 0.23 b$ & $5.7 \pm 0.33 a b$ \\
\hline & 7 & $4.84 \pm 0.42 a$ & $5.39 \pm 0.06 b$ & $5.86 \pm 0.09 b$ & $5.72 \pm 0.33 a$ & $4.29 \pm 0.11 b$ & $4.75 \pm 0.33 b$ \\
\hline & 14 & $6.42 \pm 0.63 a$ & $5.74 \pm 0.37 a$ & $5.39 \pm 0.46 a$ & $5.85 \pm 0.12 a$ & $5.49 \pm 0.19 a$ & $5.76 \pm 0.44 a$ \\
\hline & 30 & $5.01 \pm 0.44 a$ & $6.39 \pm 0.22 b$ & $6.46 \pm 0.41 b$ & $5.75 \pm 0.12 a$ & $5.41 \pm 0.24 a$ & $5.52 \pm 0.47 a$ \\
\hline & Mean & 5.35 & 5.67 & 5.42 & 6.07 & 5.72 & 5.47 \\
\hline & $\pm S D$ & 0.73 & 0.44 & 0.78 & 0.79 & 1.10 & 0.41 \\
\hline & Range & $4.67-6.42$ & 5.34-6.39 & $4.55-6.47$ & $5.72-7.47$ & $4.30-7.3$ & $4.75-5.76$ \\
\hline & CV & $13.74 \%$ & $7.68 \%$ & $14.31 \%$ & $13.03 \%$ & $19.19 \%$ & $7.48 \%$ \\
\hline \multirow{9}{*}{$\begin{array}{l}\text { Silt } \\
\%\end{array}$} & 1 & $76.95 \pm 3.2 a$ & $69.81 \pm 1.05 b$ & $66.77 \pm 1.35 b$ & $79.95 \pm 2.26 a$ & $76.9 \pm 5.93 a$ & $75.34 \pm 0.18 a$ \\
\hline & 3 & $72.99 \pm 1.01 a$ & $69.14 \pm 3.38 \mathrm{ab}$ & $64.36 \pm 4.56 b$ & $75.05 \pm 6.62 a$ & $75.56 \pm 1.81 a$ & $73.06 \pm 4.89 a$ \\
\hline & 7 & $66.72 \pm 4.28 a$ & $75.03 \pm 0.62 a$ & $70.03 \pm 2.09 a$ & $73.66 \pm 7.19 a$ & $65.05 \pm 2.67 a$ & $73.31 \pm 6.41 a$ \\
\hline & 14 & $77.95 \pm 1.39 a$ & $74.81 \pm 1.05 a$ & $66.12 \pm 2.19 b$ & $76.23 \pm 3.36 a$ & $82.07 \pm 0.91 b$ & $76.57 \pm 2.38 a$ \\
\hline & 30 & $69.31 \pm 6.79 a$ & $74.65 \pm 1.84 a$ & $66.47 \pm 3.39 a$ & $80.54 \pm 2.06 a$ & $76.32 \pm 4.77 a$ & $80.32 \pm 2.98 a$ \\
\hline & Mean & 72.79 & 72.69 & 66.75 & 77.09 & 75.18 & 75.72 \\
\hline & $\pm S D$ & 4.82 & 2.95 & 2.06 & 3.03 & 6.21 & 2.95 \\
\hline & Range & $66.72-77.96$ & $69.14-75.03$ & $64.37-70.03$ & $73.67-80.54$ & $65.05-82.07$ & $73.06-80.32$ \\
\hline & CV & $6.62 \%$ & $4.05 \%$ & $3.08 \%$ & $3.93 \%$ & $8.27 \%$ & $3.90 \%$ \\
\hline \multirow{9}{*}{$\begin{array}{l}\text { Sand } \\
\%\end{array}$} & 1 & $15.3 \pm 0.77 a$ & $24.81 \pm 1.11 b$ & $27.34 \pm 0.67 c$ & $14.44 \pm 0.37 a$ & $20.27 \pm 1.7 b$ & $19.14 \pm 0.52 b$ \\
\hline & 3 & $22.33 \pm 0.94 a$ & $27.4 \pm 1.38 b$ & $33.13 \pm 2.6 \mathrm{c}$ & $17.07 \pm 1.43 a$ & $18.31 \pm 1.58 a$ & $19.56 \pm 1.49 a$ \\
\hline & 7 & $24.94 \pm 1.89 a$ & $19.56 \pm 0.55 b$ & $24.76 \pm 1.98 a$ & $23.28 \pm 1.65 a$ & $33.01 \pm 2.65 b$ & $23.93 \pm 2.13 a$ \\
\hline & 14 & $14.96 \pm 0.82 \mathrm{a}$ & $19.45 \pm 0.97 b$ & $28.48 \pm 2.34 c$ & $19.91 \pm 1.32 \mathrm{a}$ & $12.42 \pm 0.75 b$ & $16 \pm 0.78 c$ \\
\hline & 30 & $22.56 \pm 2.01 \mathrm{ab}$ & $19.62 \pm 1.62 a$ & $25.53 \pm 0.33 b$ & $16.69 \pm 1.6 a$ & $13.26 \pm 0.82 b$ & $12.48 \pm 0.7 b$ \\
\hline & Mean & 20.02 & 22.17 & 27.85 & 18.28 & 19.46 & 18.23 \\
\hline & $\pm S D$ & 4.58 & 3.71 & 3.30 & 3.40 & 8.27 & 4.28 \\
\hline & Range & $14.96-24.94$ & $19.45-27.40$ & $24.76-33.14$ & $14.44-23.28$ & $12.43-33.01$ & $12.48-23.94$ \\
\hline & CV & $22.88 \%$ & $16.73 \%$ & $11.84 \%$ & $18.62 \%$ & $42.49 \%$ & $23.46 \%$ \\
\hline
\end{tabular}

a. bare ground soil; b: vegetated area soil; CK: 0\% PET added; M1: 7\% PET added; M2: 28\% PET added; clay grain (<2 $\mu$ m); silt grain (2-20 $\mu$ m); sand grain $(>20 \mu \mathrm{m}) ; \pm$ SD: standard deviation; CV: coefficient of variation (\%); different lowercase letters (a / b / c) indicate different amounts of PET added The particle size distribution of PET was significantly different $(p<0.05)$

For the soil silt (Figure 7. C, D), the fluctuation of bare soil and vegetation soil after pet treatment was low, and the variation range was 64.37$77.96 \%$ and $65.05-82.07 \%$, respectively. The results of difference analysis showed that the percentage of silt in bare soil treated with ${ }^{\mathrm{a}} \mathrm{M} 1$ on the 7th and 30th day was significantly different from that of ${ }^{\mathrm{a}} \mathrm{CK}$; the percentage of silt in bare soil treated with ${ }^{\mathrm{a}} \mathrm{M} 2$ on the $1 \mathrm{st}$, 7th and 30 th day was significantly different from that of ${ }^{\mathrm{a}} \mathrm{CK}(\mathrm{p}<0.05$, Table 2). However, after pet treatment, the distribution of silt particles in the vegetation area was significantly different from that in the ${ }^{\mathrm{b}} \mathrm{CK}$ group only on the 14 th day of ${ }^{\mathrm{b}} \mathrm{M} 1$ treatment $(\mathrm{p}<0.05)$. Combined with $\mathrm{CV}$ analysis, the $\mathrm{CV}$ values of silt in bare soil and vegetation soil after adding pet were less than $10 \%$, indicating that the silt can still maintain a relatively stable distribution state after adding pet.

For soil sand (Figure 7. E, F), the change of bare soil and vegetation soil after pet cultivation fluctuated higher. The sand proportion of bare soil after ${ }^{\mathrm{a}} \mathrm{M} 1$ and ${ }^{\mathrm{a}} \mathrm{M} 2$ treatment was $19.45-27.40 \%$ and $24.76-33.14 \%$ respectively, while that of vegetation soil after ${ }^{\mathrm{b}} \mathrm{M} 1$ and ${ }^{\mathrm{b}} \mathrm{M} 2$ treatment was $12.43-33.01 \%$ and $12.48-23.94 \%$ respectively. The results of the different analysis showed that there was no significant difference in the 
percentage of sand grains on the 30th day and the 7th day of ${ }^{\mathrm{a}} \mathrm{M} 1$ and ${ }^{\mathrm{a}} \mathrm{M} 2$ treatments in bare soil compared with CK ( $\left.\mathrm{p}<0.05\right)$; there was a significant difference in the percentage of sand grains on the 1 st day, the 7 th day, the 14 th day and the 30 th day of ${ }^{b} \mathrm{M} 1$ and ${ }^{b} \mathrm{M} 2$ treatments in vegetation area compared with ${ }^{\mathrm{b}} \mathrm{CK}(\mathrm{p}<0.05)$. Combined with mean value analysis, it was found that the proportion of sand particles in bare soil and vegetation soil increased in varying degrees after pet cultivation (Table 2). Besides, combined with CV analysis, it was found that the CV values of sand proportion in bare soil and vegetation area after pet cultivation were higher (> 10\%). Among them, the CV values of bare soil treated with ${ }^{\mathrm{a}} \mathrm{M} 1$ and ${ }^{\mathrm{a}} \mathrm{M} 2$ were less than $17 \%$, and the specific order was $\mathrm{CV}-{ }^{\mathrm{a}} \mathrm{M} 1$ (16.73\%) > CV- ${ }^{\mathrm{a}} \mathrm{M} 2(11.84 \%)$; the $\mathrm{CV}$ values of vegetation soil treated with ${ }^{\mathrm{b}} \mathrm{M} 1$ and ${ }^{\mathrm{b}} \mathrm{M} 2$ were more than $20 \%$, and the specific order was CV-b ${ }^{\mathrm{b}} 1$ ( $\left.42.49 \%\right)>\mathrm{CV}^{\mathrm{b}} \mathrm{M} 2$ (23.46\%).

In summary, the proportion of clay particles in the soil after PET addition to the culture decreases, while the proportion of chalk particles remains stable, but the proportion of sand particles increases. Besides, on the whole, the CV values of the soil in the vegetation zone after the addition of PET are higher than those of the bare ground soil, indicating that the distribution of the proportion of each grain size in the soil in the vegetation zone is more unstable and fluctuates more after the PET treatment than in the bare ground soil, which can also indicate to a certain extent that the grain size distribution of the soil in the vegetation zone is more susceptible to the influence of PET.

\section{\#Figure 7\#}

\subsubsection{Effect of PET on the pH of wetland soil}

Figure 8 shows the changes of soil pH after adding pet to the bare soil and vegetation soil of mangrove restoration wetland, and Table 3 shows the statistical analysis results of soil $\mathrm{pH}$. The $\mathrm{pH}$ values of bare soil treated with ${ }^{\mathrm{a}} \mathrm{M} 1$ and ${ }^{\mathrm{a}} \mathrm{M} 2$ were 7.83-7.93 and 7.77-7.90, respectively, with a small range (Figure 8.A). Combined with the difference analysis, it was found that there was no significant difference in the $\mathrm{pH}$ of bare soil after ${ }^{\mathrm{a}} \mathrm{M} 1$ and ${ }^{\mathrm{a}} \mathrm{M} 2$ treatment compared with that of $\mathrm{CK}(\mathrm{p}>0.05$, Table 3$)$. CV analysis results also showed that the $\mathrm{CV}$ values of all treatments were smaller (all < 1.3\%) (Table 3). However, it should be noted that from the 14 th day after ${ }^{\mathrm{a}} \mathrm{M} 1$ and ${ }^{\mathrm{a}} \mathrm{M} 2$ treatment, the soil pH of bare land was significantly lower than that of CK (Figure 8. A). For the soil in the vegetation area, the $\mathrm{pH}$ values after treatment with ${ }^{\mathrm{b}} \mathrm{M} 1$ and ${ }^{\mathrm{b}} \mathrm{M} 2 \mathrm{were}^{7.03-7.44}$ and 6.94-7.45, respectively, with great fluctuation, and the 14th day after treatment was the turning point, showing a trend of first rising and then declining (Figure 8. B). Besides, there were significant differences in soil pH of vegetation area on the 3rd day after b 1 treatment, the $3 r d$ day after ${ }^{b} \mathrm{M} 2$ treatment, and the 7 th day after ${ }^{\mathrm{b}} \mathrm{M} 2$ treatment $(\mathrm{p}<0.05$, Table 3$)$. Combined with $\mathrm{CV}$ analysis, it was found that the $\mathrm{CV}$ value of vegetation soil after pet treatment was higher than that of bare soil (all $>2 \%$ ). In terms of mean change (Table 3 ), the pH value of bare soil and vegetation soil after M1 and M2 treatment had little change compared with CK, but the overall trend was still downward, indicating that pet increased soil acidity to a certain extent, which was worthy of further study.

Table 3

Statistical analysis results of $\mathrm{pH}$.

\begin{tabular}{|c|c|c|c|c|c|c|}
\hline Day & ${ }^{\mathrm{a}} 0 \%$ & $a_{7 \%}$ & ${ }^{a} 28 \%$ & ${ }^{b} 0 \%$ & $b_{7 \%}$ & $b_{28 \%}$ \\
\hline 1 & $7.91 \pm 0.1 \mathrm{a}$ & $7.91 \pm 0.11 \mathrm{a}$ & $7.81 \pm 0.05 a$ & $7.12 \pm 0.08 \mathrm{a}$ & $7.16 \pm 0.03 a$ & $6.94 \pm 0.01 \mathrm{a}$ \\
\hline 3 & $7.84 \pm 0.05 a$ & $7.85 \pm 0.01 \mathrm{a}$ & $7.78 \pm 0.08 a$ & $7.29 \pm 0 \mathrm{a}$ & $7.2 \pm 0.01 \mathrm{~b}$ & $7.22 \pm 0.02 b$ \\
\hline 7 & $7.74 \pm 0.05 \mathrm{a}$ & $7.83 \pm 0.02 \mathrm{a}$ & $7.81 \pm 0.03 a$ & $7.3 \pm 0.03 \mathrm{a}$ & $7.23 \pm 0.02 \mathrm{a}$ & $7.25 \pm 0.02 a b$ \\
\hline 14 & $7.84 \pm 0.06 \mathrm{a}$ & $7.87 \pm 0.07 \mathrm{a}$ & $7.81 \pm 0.02 \mathrm{a}$ & $7.44 \pm 0.23 \mathrm{a}$ & $7.44 \pm 0.23 \mathrm{a}$ & $7.44 \pm 0.23 \mathrm{a}$ \\
\hline 30 & $8.02 \pm 0.04 \mathrm{a}$ & $7.92 \pm 0.06 \mathrm{a}$ & $7.9 \pm 0.06 \mathrm{a}$ & $6.96 \pm 0.1 \mathrm{a}$ & $7.03 \pm 0 \mathrm{a}$ & $7.1 \pm 0.02 \mathrm{a}$ \\
\hline Mean & 7.87 & 7.88 & 7.82 & 7.23 & 7.21 & 7.19 \\
\hline $\pm S D$ & 0.10 & 0.04 & 0.05 & 0.19 & 0.15 & 0.19 \\
\hline Range & 7.97.84-8.02 & 7.83-7.93 & 7.77-7.90 & $6.96-7.45$ & 7.03-7.44 & $6.94-7.45$ \\
\hline $\mathrm{CV}$ & $1.28 \%$ & $0.50 \%$ & $0.58 \%$ & $2.57 \%$ & $2.05 \%$ & $2.62 \%$ \\
\hline
\end{tabular}

\#Figure 8\#

\subsubsection{Effects of pet on total nitrogen, ammonium nitrogen and nitrate nitrogen in wetland soil}

Figure 9 shows the changes of soil total nitrogen $(\mathrm{TN})$, ammonium nitrogen $\left(\mathrm{NH}_{4}{ }^{+}-\mathrm{N}\right)$, and nitrate-nitrogen $\left(\mathrm{NO}_{3}{ }^{-}-\mathrm{N}\right)$ in the bare soil and vegetation area of mangrove restoration wetland after adding pet culture. Table 4-6 shows the statistical analysis results of soil total nitrogen (TN), ammonium nitrogen $\left(\mathrm{NH}_{4}{ }^{+}-\mathrm{N}\right)$, and nitrate-nitrogen $\left(\mathrm{NO}_{3}{ }^{-} \mathrm{N}\right)$ respectively. The $\mathrm{TN}$ of bare soil treated with ${ }^{\mathrm{a}} \mathrm{M} 1$ and ${ }^{\mathrm{a}} \mathrm{M} 2 \mathrm{was} 140.43-450.43 \mathrm{mg} / \mathrm{kg}$ 
and $66.03-462.83 \mathrm{mg} / \mathrm{kg}$, respectively, with a wide range (Table 3.4). After AM1 treatment, TN increased first and then stabilized, while after ${ }^{\mathrm{a}} \mathrm{M} 2$ treatment, TN increased first and then decreased (Figure 9. A). The results of the different analysis showed that the TN of bare soil treated with ${ }^{\mathrm{a}} \mathrm{M} 1$ and ${ }^{\mathrm{a}} \mathrm{M} 2$ on the first day and the 30th day was significantly higher than that of $\mathrm{CK}(\mathrm{p}<0.05)$, and the mean value showed that the TN of bare soil treated with ${ }^{\mathrm{a}} \mathrm{M} 2$ was $21.07 \%$ lower than that of CK. The changing trend of soil TN in vegetation area after pet cultivation was different from that in bare land. The soil TN in vegetation area under ${ }^{\mathrm{b}} \mathrm{M} 1$ and ${ }^{\mathrm{b}} \mathrm{M} 2$ treatments were 103.23-779.02 mg/kg and 301.63-729.42 mg/kg, respectively, with a wide range of changes. The soil TN in vegetation area under both treatments showed a trend of first decreasing and then increasing, and then slowly increasing (Figure 9. B). However, compared with ${ }^{\mathrm{b}} \mathrm{CK}$, the average TN of vegetation soil under ${ }^{\mathrm{b}} \mathrm{M} 1$ and ${ }^{\mathrm{b}} \mathrm{M} 2$ treatments was still $14.31 \%$ lower than that of CK (Table 4). CV analysis results showed that the CV values of TN in bare soil and vegetated soil after pet cultivation were higher, especially in bare soil $>50 \%$, and in vegetated soil M1 treatment $>50 \%$ (Table 4 ).

Table 4

Statistical analysis results of total nitrogen $(\mathrm{TN}, \mathrm{mg} / \mathrm{kg})$.

\begin{tabular}{|c|c|c|c|c|c|c|}
\hline Day & ${ }^{\mathrm{a}} 0 \%$ & $a^{3} \%$ & $a_{28} \%$ & ${ }^{b} 0 \%$ & b7\% & $b_{2} 28 \%$ \\
\hline 1 & $338.82 \pm 10.73$ a & $196.22 \pm 18.59 \mathrm{~b}$ & $66.02 \pm 0 \mathrm{c}$ & $754.22 \pm 32.21 \mathrm{a}$ & $797.62 \pm 10.73$ a & $729.42 \pm 56.82 \mathrm{a}$ \\
\hline 3 & $103.22 \pm 0 \mathrm{a}$ & $152.82 \pm 21.47 \mathrm{a}$ & $165.22 \pm 42.95 b$ & $345.02 \pm 37.19 a$ & $103.22 \pm 0 \mathrm{~b}$ & $301.62 \pm 10.73 \mathrm{a}$ \\
\hline 7 & $165.22 \pm 21.47 a b$ & $140.42 \pm 18.59 \mathrm{~b}$ & $190.02 \pm 10.73 \mathrm{a}$ & $407.02 \pm 28.41 \mathrm{a}$ & $295.42 \pm 21.47 b$ & $462.82 \pm 28.41 \mathrm{C}$ \\
\hline 14 & $444.22 \pm 38.71$ a & $450.42 \pm 10.73$ a & $462.82 \pm 28.41 \mathrm{a}$ & $704.62 \pm 10.73 \mathrm{a}$ & $655.02 \pm 21.47 b$ & $419.42 \pm 18.59 \mathrm{c}$ \\
\hline 30 & $301.62 \pm 28.41 \mathrm{a}$ & $450.42 \pm 38.71 b$ & $183.82 \pm 10.73 \mathrm{c}$ & $779.02 \pm 10.73$ a & $710.82 \pm 21.47 b$ & $648.82 \pm 10.73 \mathrm{c}$ \\
\hline Mean & 270.63 & 278.07 & 213.59 & 597.98 & 512.42 & 512.42 \\
\hline $\pm S D$ & 136.82 & 158.70 & 148.05 & 205.55 & 298.15 & 174.10 \\
\hline Range & $103.23-444.23$ & $140.43-450.43$ & $66.03-462.83$ & $345.03-779.02$ & 103.23-797.62 & $301.63-729.42$ \\
\hline CV & 50.56 & 57.07 & 69.31 & 34.37 & 58.18 & 33.97 \\
\hline
\end{tabular}

Table 5

Statistical analysis results of $\mathrm{NH} 4+-\mathrm{N}(\mathrm{mg} / \mathrm{kg})$.

\begin{tabular}{|c|c|c|c|c|c|c|}
\hline Day & ${ }^{\mathrm{a}} 0 \%$ & $a_{7 \%}$ & ${ }^{a} 28 \%$ & ${ }^{b} 0 \%$ & $b_{7 \%}$ & $b_{28 \%}$ \\
\hline 1 & $27.4 \pm 2.65 \mathrm{a}$ & $30.65 \pm 0.06 a$ & $18.8 \pm 1.11 b$ & $17.77 \pm 0.73 \mathrm{a}$ & $17.58 \pm 1.36 \mathrm{a}$ & $17.58 \pm 0.89 a$ \\
\hline 3 & $21.05 \pm 1.78 \mathrm{a}$ & $25.81 \pm 1.16 b$ & $18.73 \pm 0.98 \mathrm{a}$ & $15.77 \pm 1.36 \mathrm{a}$ & $15.15 \pm 0.9 \mathrm{a}$ & $16.36 \pm 1.02 \mathrm{a}$ \\
\hline 7 & $25.11 \pm 2.33 \mathrm{a}$ & $23.38 \pm 0.33 \mathrm{a}$ & $19.54 \pm 0.16 b$ & $17.88 \pm 1.5 \mathrm{a}$ & $13.12 \pm 1.28 b$ & $24.45 \pm 0.89 c$ \\
\hline 14 & $22.64 \pm 1.07 \mathrm{a}$ & $20.06 \pm 0.58 b$ & $19.83 \pm 0.29 b$ & $19.24 \pm 1.61 \mathrm{a}$ & $20.09 \pm 1.73$ a & $18.95 \pm 1.15 a$ \\
\hline 30 & $18.69 \pm 0.33 \mathrm{a}$ & $21.68 \pm 1.88 b$ & $19.24 \pm 0.06 \mathrm{a}$ & $24.45 \pm 2.23 \mathrm{a}$ & $7.84 \pm 0.62 b$ & $4.93 \pm 0.44 \mathrm{c}$ \\
\hline Mean & 22.98 & 24.32 & 19.23 & 19.03 & 14.76 & 16.46 \\
\hline $\pm S D$ & 3.40 & 4.13 & 0.47 & 3.28 & 4.67 & 7.15 \\
\hline Range & $18.69-27.40$ & $20.06-30.65$ & $18.73-19.84$ & $15.78-24.45$ & $7.84-20.10$ & $4.93-24.45$ \\
\hline $\mathrm{CV}$ & 14.80 & 16.99 & 2.46 & 17.21 & 31.62 & 43.42 \\
\hline
\end{tabular}


Table 6

Statistical analysis results of NO3--N (mg/kg).

\begin{tabular}{|c|c|c|c|c|c|c|}
\hline Day & ${ }^{\mathrm{a}} 0 \%$ & a $7 \%$ & a $28 \%$ & ${ }^{b} 0 \%$ & b7\% & $b_{28 \%}$ \\
\hline 1 & $11.23 \pm 0.92 \mathrm{a}$ & $7.97 \pm 0.75 b$ & $23.93 \pm 2.15 \mathrm{c}$ & $44.1 \pm 0.17 \mathrm{ab}$ & $42.56 \pm 1.1 \mathrm{a}$ & $44.68 \pm 0.84 \mathrm{~b}$ \\
\hline 3 & $8.81 \pm 0.65 a$ & $6.77 \pm 0.33 b$ & $26.19 \pm 1.29 \mathrm{c}$ & $49.82 \pm 2.39 \mathrm{a}$ & $42.19 \pm 2.67 b$ & $46.11 \pm 0.46 a b$ \\
\hline 7 & $11.99 \pm 0.78 \mathrm{a}$ & $11.59 \pm 1.03 \mathrm{a}$ & $30.08 \pm 2 b$ & $54.23 \pm 4.25 \mathrm{a}$ & $41.02 \pm 0.95 b$ & $47.59 \pm 1.44 \mathrm{c}$ \\
\hline 14 & $15.47 \pm 1.53$ a & $19.28 \pm 1.62 b$ & $35.23 \pm 0.42 c$ & $49.31 \pm 0.62 \mathrm{a}$ & $51.16 \pm 2.36 \mathrm{ab}$ & $53.64 \pm 1.26 \mathrm{c}$ \\
\hline 30 & $1.41 \pm 0.1 \mathrm{a}$ & $1.43 \pm 0.08 \mathrm{a}$ & $17.18 \pm 1.14 b$ & $93.83 \pm 1.51 \mathrm{a}$ & $103.12 \pm 1.98 b$ & $104.71 \pm 4.03 b$ \\
\hline Mean & 9.79 & 9.42 & 26.53 & 58.26 & 56.01 & 59.35 \\
\hline $\pm S D$ & 5.25 & 6.61 & 6.76 & 20.21 & 26.64 & 25.59 \\
\hline Range & $1.42-15.48$ & $1.44-19.29$ & $17.19-35.23$ & $44.10-93.83$ & $41.03-103.12$ & $44.69-104.71$ \\
\hline $\mathrm{CV}$ & 53.67 & 70.23 & 25.47 & 34.68 & 47.56 & 43.11 \\
\hline
\end{tabular}

a: bare soil; b: soil in vegetated areas; \pm SD: standard deviation; CV: coefficient of variation (\%); different lowercase letters (a / b / c) indicate significant differences $(\mathrm{p}<0.05)$ in the $\mathrm{NO}_{3}{ }^{-}-\mathrm{N}$ distribution for different additions of PET.

For the soil ammonium nitrogen $\left(\mathrm{NH}_{4}{ }^{+} \mathrm{N}\right)$, the changing trend of bare soil and vegetation area soil under pet treatment was obvious (Figure 9 . $\mathrm{C}$, D). The content of $\mathrm{NH}_{4}{ }^{+}-\mathrm{N}$ in bare soil under the treatment of ${ }^{\mathrm{a}} \mathrm{M} 1$ is $20.06-30.65 \mathrm{mg} / \mathrm{kg}$, which has a large range of changes and the overall trend of decline; while the content of $\mathrm{NH}_{4}{ }^{+}-\mathrm{N}$ in the soil treated with ${ }^{\mathrm{a}} \mathrm{M} 2$ is $18.73-19.84 \mathrm{mg} / \mathrm{kg}$, which has not changed significantly (Figure 9 . C). Besides, the $\mathrm{NH}_{4}{ }^{+}-\mathrm{N}$ content of bare soil was significantly higher than that of the CK on the first day, 7th day, and 14th day after treatment with ${ }^{\mathrm{a}} \mathrm{M} 2\left(\mathrm{p}<0.05\right.$, Table 5). The content of $\mathrm{NH}_{4}{ }^{+}-\mathrm{N}$ in vegetation area after ${ }^{\mathrm{b}} \mathrm{M} 1$ and ${ }^{\mathrm{b}} \mathrm{M} 2$ treatment was larger, which were $1.84-20.10 \mathrm{mg} / \mathrm{kg}$ and 4.93-24.45 mg/kg respectively, and had some changes (Figure 9. D). The $\mathrm{NH}_{4}{ }^{+}-\mathrm{N}$ content of the soil in the vegetation area was significantly reduced by $67.93 \%$ and $79.84 \%$ compared with that of the ${ }^{\mathrm{b}} \mathrm{CK}$ group on the 30 th day after ${ }^{\mathrm{b}} \mathrm{M} 1$ and ${ }^{\mathrm{b}} \mathrm{M} 2$ treatment ( $<<0.05$, Table 5 ). According to $\mathrm{CV}$ analysis, it was found that the $\mathrm{CV}$ value of $\mathrm{NH}_{4}{ }^{+}-\mathrm{N}$ was lower in bare soil after pet treatment, especially for $2.46 \%$ under the treatment of ${ }^{a} \mathrm{M} 2$, while that of vegetation area soil treated with PET was generally higher than $30 \%$. For nitrate-nitrogen $\left(\mathrm{NO}_{3}{ }^{-}-\mathrm{N}\right)$, the $\mathrm{content}^{-}$of $\mathrm{NO}_{3}{ }^{-}-\mathrm{N}$ in bare soil treated with ${ }^{\mathrm{a}} \mathrm{M} 1$ is $1.44-19.29 \mathrm{mg} / \mathrm{kg}$, while that of soil treated with ${ }^{\mathrm{a}} \mathrm{M} 2$ is $17.19-35.23 \mathrm{mg} / \mathrm{kg}$, with a large range of changes, and the overall trend is decreasing (Figure 9. E). The mean $\mathrm{NO}_{3}{ }^{-} \mathrm{N}$ content of bare soil treated with ${ }^{\mathrm{a}} \mathrm{M} 2$ was significantly higher than that of the $\mathrm{CK}$, but there was no significant difference between ${ }^{\mathrm{a}} \mathrm{M} 1$ and ${ }^{\mathrm{a}} \mathrm{CK}$. The $\mathrm{NO}_{3}{ }^{-} \mathrm{N}$ content of the soil in vegetation area after ${ }^{\mathrm{b}} \mathrm{M} 1$ and ${ }^{\mathrm{b}} \mathrm{M} 2$ treatment was significantly higher than CK $(p<0.05$, Table 6), and there was a significant upward trend (Figure 9. F), which was contrary to the experimental results of soil ammonium nitrogen $\left(\mathrm{NH}_{4}{ }^{+}-\mathrm{N}\right)$. Combined with $\mathrm{CV}$ analysis, the $\mathrm{CV}$ value of $\mathrm{NO}_{3}{ }^{-} \mathrm{N}$ was more than $25 \%$ under various treatments.

\#Figure 9\#

\subsubsection{Effects of pet on total phosphorus and phosphatase in wetland soil}

Figure 10 shows the change of total phosphorus (TP) content in the bare soil and vegetation area of mangrove restoration wetland after pet culture. Table 7 shows the statistical analysis results of total soil phosphorus (TP). In this study, the content of TP in bare soil is generally $352.27-$ $479.43 \mathrm{mg} / \mathrm{kg}$, and the range of change is small, and the change curve of TP fluctuates slightly (Figure 10. A). Besides, the TP content of bare soil treated with ${ }^{\mathrm{a}} \mathrm{M} 1$ and ${ }^{\mathrm{a}} \mathrm{M} 2$ was significantly lower than that of the CK. After the treatment of ${ }^{\mathrm{a}} \mathrm{M} 2$, except for $402.31 \mathrm{mg} / \mathrm{kg}$ in the samples on the 7th day, the TP content of other samples was less than $400 \mathrm{mg} / \mathrm{kg}$, and the mean TP content of the treated with ${ }^{\mathrm{a}} \mathrm{M} 2 \mathrm{was} 13.36 \%$ lower than that of the CK group ( $p<0.05$, Table 7). The total phosphorus content in vegetation area was $699.28-1229.24 \mathrm{mg} / \mathrm{kg}$, and the range of change is large, and the change curve of total phosphorus (TP) fluctuates greatly. The total phosphorus (TP) of soil treated with ${ }^{b} \mathrm{M} 1$ and ${ }^{b} \mathrm{M} 2$ increased first and then decreased, but increased again on the 14th day (Figure 10. B). Besides, the total phosphorus (TP) of soil treated with bM1 and bM2 in vegetation area was significantly lower than that of ${ }^{b} \mathrm{CK}(\mathrm{p}<0.05$, Table 7$)$, especially in the ${ }^{\mathrm{b}} \mathrm{M} 2$ treatment group, the mean TP content was $18.73 \%$ lower than that of the ${ }^{\mathrm{b}} \mathrm{CK}$. According to $\mathrm{CV}$ analysis, the $\mathrm{CV}$ values of total phosphorus (TP) in bare soil treated with ${ }^{\mathrm{a}} \mathrm{M} 1$ and ${ }^{\mathrm{a}} \mathrm{M} 2 \mathrm{were}$ $8.06 \%$, and $5.45 \%$ respectively; while the CV values of soil TP in vegetation area treated with $\mathrm{Bm} 1$ and ${ }^{\mathrm{b}} \mathrm{M} 2$ were more than $13 \%, 14.02 \%$, and $13.26 \%$ respectively. It was found that the distribution of phosphorus in mangrove restoration wet soil would make the soil phosphorus distribution uneven after pet cultivation. 
Table 7

Statistical analysis results of total phosphorus (TP, $\mathrm{mg} / \mathrm{kg}$ )

\begin{tabular}{|c|c|c|c|c|c|c|}
\hline Day & ${ }^{\mathrm{a}} 0 \%$ & $a_{7 \%}$ & ${ }^{a} 28 \%$ & ${ }^{b} 0 \%$ & b7\% & $\mathrm{b}_{28 \%}$ \\
\hline 1 & $451.53 \pm 13.67$ a & $426.1 \pm 15.08 \mathrm{a}$ & $370.31 \pm 18.23 b$ & $989.69 \pm 37.61 \mathrm{a}$ & $915.86 \pm 53.78$ a & $699.28 \pm 31.53 b$ \\
\hline 3 & $431.84 \pm 18.23$ a & $408.05 \pm 10.63 a$ & $352.26 \pm 5.05 b$ & $882.22 \pm 26.14$ a & $933.91 \pm 20.22 b$ & $838.74 \pm 8.03$ a \\
\hline 7 & $473.68 \pm 16.73$ a & $435.94 \pm 6.13 b$ & $402.31 \pm 7.6 \mathrm{c}$ & $1014.3 \pm 48.45 \mathrm{a}$ & $1178.38 \pm 45.51$ b & $974.1 \pm 52.36 \mathrm{a}$ \\
\hline 14 & $412.97 \pm 16.44 \mathrm{a}$ & $387.54 \pm 5.05 b$ & $362.93 \pm 2.32 \mathrm{c}$ & $1229.24 \pm 43.67 \mathrm{a}$ & $855.15 \pm 6.13 b$ & $819.87 \pm 46.23 b$ \\
\hline 30 & $398.2 \pm 5.31$ a & $479.42 \pm 40.18 \mathrm{~b}$ & $390.82 \pm 5.31 \mathrm{c}$ & $1151.3 \pm 35.32 \mathrm{a}$ & $1120.13 \pm 30.23 \mathrm{a}$ & $965.08 \pm 25.91 b$ \\
\hline Mean & 433.65 & 427.41 & 375.73 & 1053.36 & 1000.69 & 859.42 \\
\hline $\pm S D$ & 30.04 & 34.44 & 20.48 & 137.29 & 140.25 & 113.97 \\
\hline Range & $398.21-473.68$ & $387.54-479.43$ & $352.27-402.31$ & $882.23-1229.24$ & $855.15-1178.38$ & 699.28-974.11 \\
\hline CV & 6.93 & 8.06 & 5.45 & 13.03 & 14.02 & 13.26 \\
\hline
\end{tabular}

\#Figure 10\#

Figure 11 shows the characteristics of soil phosphatase changes in bare ground soil and vegetated area soil in mangrove restoration wetlands after the addition of PET culture, and Table 8 shows the results of statistical analysis of soil phosphatase. The phosphatase content of the bare ground soil in this study was generally low at $0.32-0.68 \mathrm{mg} /(\mathrm{g} \cdot \mathrm{h})$, with a small range of variation and small fluctuations in the phosphatase change curve (Figure 3.11 A). Furthermore, from the analysis of variance, the phosphatase of the bare ground soils treated with ${ }^{a} \mathrm{M} 1 \mathrm{was}$ only significantly different from the ${ }^{\mathrm{a}} \mathrm{CK}$ for samples on days 14 and 30 of incubation, whereas the phosphatase content of the ${ }^{\mathrm{a}} \mathrm{M} 2$ treated soils was significantly different from the ${ }^{\mathrm{a}} \mathrm{CK}$ for both days 3, 7 and 14 of incubation, which were significantly lower than the ${ }^{\mathrm{a}} \mathrm{CK}$, and significantly higher than the a CK on days 1 and 30 ( $p<0.05$, Table 8). The overall higher phosphatase levels of $1.42-2.01 \mathrm{mg} /(\mathrm{g} \cdot \mathrm{h})$ in the vegetation zone soils showed a wide range of variability and fluctuating phosphatase profiles (Figure 11. B). From the analysis of variance, phosphatase in the vegetation zone soils treated with ${ }^{\mathrm{b}} \mathrm{M} 1$ differed significantly from the $\mathrm{CK}$ except on day 1 , and phosphatase treated with ${ }^{\mathrm{b}} \mathrm{M} 2$ differed significantly from the CK on days 3,14 , and 30 ( $<<0.05$, Table.8), and the phosphatase levels were all lower after ${ }^{b} \mathrm{M} 2$ treatment than the lower $\mathrm{CK}$ phosphatase levels. From the mean analysis, the phosphatase in the vegetated area soils was $10.82 \%$ and $19.07 \%$ lower after the ${ }^{\mathrm{b}} \mathrm{M} 1$ and ${ }^{\mathrm{b}} \mathrm{M} 2$ treatments, respectively, compared to the ${ }^{\mathrm{b}} \mathrm{CK}$ group. Besides, the CV analysis showed that the CV values of soil phosphatase in bare ground soils treated with ${ }^{\mathrm{a}} \mathrm{M} 1$ and ${ }^{\mathrm{a}} \mathrm{M} 2$ were $15.14 \%$ and $23.69 \%$, respectively; while the $\mathrm{CV}$ values of soil phosphatase in vegetated area soils treated with ${ }^{\mathrm{b}} \mathrm{M} 1$ and ${ }^{\mathrm{b}} \mathrm{M} 2$ were $9.62 \%$ and $9.04 \%$.

Table 8

Statistical analysis results of phosphatase $(\mathrm{mg} /(\mathrm{g} \cdot \mathrm{h}))$.

\begin{tabular}{|c|c|c|c|c|c|c|}
\hline Day & ${ }^{\mathrm{a}} 0 \%$ & $a_{7 \%}$ & $a_{28 \%}$ & ${ }^{b} 0 \%$ & b7\% & $\mathrm{b}_{28 \%}$ \\
\hline 1 & $0.49 \pm 0.02 \mathrm{a}$ & $0.48 \pm 0 \mathrm{a}$ & $0.52 \pm 0 \mathrm{~b}$ & $1.86 \pm 0.09 a$ & $1.67 \pm 0.14 \mathrm{a}$ & $1.78 \pm 0.02 \mathrm{a}$ \\
\hline 3 & $0.55 \pm 0.02 a$ & $0.52 \pm 0.04 a b$ & $0.48 \pm 0 \mathrm{~b}$ & $2.15 \pm 0.09 \mathrm{a}$ & $1.6 \pm 0.02 b$ & $1.54 \pm 0.11 b$ \\
\hline 7 & $0.51 \pm 0.02 \mathrm{a}$ & $0.52 \pm 0 \mathrm{a}$ & $0.4 \pm 0.02 \mathrm{~b}$ & $1.66 \pm 0.11 \mathrm{a}$ & $1.75 \pm 0.04 \mathrm{~b}$ & $1.48 \pm 0.13 a$ \\
\hline 14 & $0.42 \pm 0.02 \mathrm{a}$ & $0.49 \pm 0.02 b$ & $0.32 \pm 0.02 \mathrm{c}$ & $1.86 \pm 0.06 \mathrm{a}$ & $1.61 \pm 0.04 b$ & $1.41 \pm 0.05 \mathrm{c}$ \\
\hline 30 & $0.48 \pm 0.04 a$ & $0.68 \pm 0.05 b$ & $0.61 \pm 0 \mathrm{~b}$ & $2.14 \pm 0 \mathrm{a}$ & $2.01 \pm 0.17 b$ & $1.61 \pm 0.04 b$ \\
\hline Mean & 0.49 & 0.54 & 0.47 & 1.94 & 1.73 & 1.57 \\
\hline $\pm S D$ & 0.05 & 0.08 & 0.11 & 0.21 & 0.17 & 0.14 \\
\hline Range & $0.42-0.55$ & $0.48-0.68$ & $0.32-0.61$ & $1.66-2.16$ & $1.61-2.01$ & $1.42-1.79$ \\
\hline CV & 9.68 & 15.14 & 23.69 & 10.84 & 9.62 & 9.04 \\
\hline
\end{tabular}

\subsubsection{Correlation analysis}


Figure 12 is the thermodynamic diagram of the correlation coefficient matrix between soil physical and chemical factors, reflecting the correlation between the characteristics of wetland soil after adding PET. Clay was significantly positively correlated with silt and TN $(p<0.01)$, and negatively correlated with sand $(p<0.05)$, but there was no significant correlation between clay and other physical and chemical factors. There was no significant correlation between silt and $\mathrm{NH}_{4}{ }^{+}-\mathrm{N}$, but an extremely significant correlation between silt and other physical and chemical factors $(\mathrm{P}<$ 0.01). Among them, silt had an extremely significant positive correlation with $\mathrm{TN}, \mathrm{NO}_{3}{ }^{-} \mathrm{N}, \mathrm{TP}$, and phosphatase $(p<0.01)$, and an extremely significant negative correlation with sand and $\mathrm{pH}(p<0.01)$. Sand also had no significant correlation with $\mathrm{NH}_{4}{ }^{+}-\mathrm{N}$, but had significant correlation with other physical and chemical factors, such as $\mathrm{pH}(p<0.05)$, total nitrogen $(p<0.01), \mathrm{NO}_{3}{ }^{-} \mathrm{N}$, TP and phosphatase $(p<0.05)$. $\mathrm{pH}$ was negatively correlated with $\mathrm{TN}, \mathrm{NO}_{3}{ }^{-} \mathrm{N}, \mathrm{TP}$ and phosphatase $(p<0.01)$, but positively correlated with $\mathrm{NH}_{4}{ }^{+}-\mathrm{N}(p<0.01)$. TN was positively

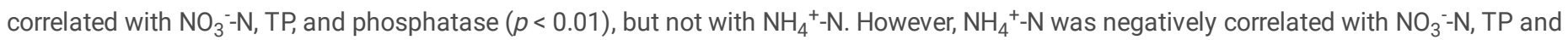
phosphatase $(p<0.01)$. $\mathrm{NO}_{3}{ }^{-} \mathrm{N}$ was positively correlated with TP and phosphatase $(p<0.01)$. TP was positively correlated with phosphatase $(p<$ 0.01). It shows that the physical and chemical factors of soil will be interrelated, influence, and transform.

\#Figure 12\#

\section{Discussion}

\subsection{Morphological characteristics and abundance distribution of soil microplastics under different planting densities in mangrove restoration wetland of Jinjiang Estuary}

\subsection{1 source apportionment and surface characteristics of soil microplastics}

Based on the complexity of migration, transportation, and transformation of microplastics in the environment, it is relatively difficult to determine the exact source of microplastics, but its source can be inferred from the appearance and physical and chemical properties of microplastics (Nor and Obbard, 2014; Peng et al., 2017). In this study, Raman spectroscopy was used to identify soil microplastics to determine whether they are microplastics and polymers (Dong et al., 2020). In this study, polypropylene (PP), polyethylene (PE) and polyethylene terephthalate (PET, polyester resin) are the main soil microplastic polymers (Figure 4). On the one hand, Jinjiang is China's shoe capital and textile and clothing production base. A large amount of wastewater containing clothing fiber from industrial production and daily life laundry may flow into Jinjiang through the drainage system and into the East China Sea through Jinjiang estuary (Deng et al., 2020). Some fibrous microplastics have obvious filamentous characteristics under the microscope (Figure 2), and their polymers are mainly PE and PP, which fully proves that one of the sources of fibrous microplastics is clothing fiber. On the other hand, pet, PE, and PP are the most abundant microplastic polymers in this study, and they are widely used in food containers, bottles, plastic bags, general packaging, clothing, fishing nets, carpets, etc. (Tan et al., 2019). However, these plastic products gather in large quantities near the estuarine wetland and become the main source of microplastics.

Scanning electron microscopy (SEM) images showed that fractures, tears, pits, flakes, and other attachments were common degradation features (Figure 5), demonstrating that surface soil microplastics in mangrove wetlands in the Jinjiang estuary had undergone varying degrees of mechanical erosion and chemical weathering, mainly due to wave action and mechanical abrasion such as sanding (Wang et al., 2017). Besides, partial degradation such as fractures, tears, and pits lead to an increase in the surface area to volume ratio of microplastics, providing more space for microorganisms to colonize and the increased surface area accelerates the degradation process (Chamas et al., 2020). The energy spectra showed that the elemental composition of the surface of different microplastic samples varied greatly, with the largest proportion of 0 atoms, but metal elements such as $\mathrm{Pb}, \mathrm{Fe}, \mathrm{Mn}, \mathrm{K}$, and $\mathrm{Na}$ were also detected on the surface of the microplastics with a higher proportion, indicating that the microplastics in the water between wetland soils can act as carriers of heavy metal ions ${ }^{216]}$. Moreover, where the surface of microplastics had depressions, cracks, or filaments, the composition of surface elements was more diverse and heavy metal elements were more easily detected, indicating that the aging of microplastics is more likely to absorb heavy metals (Ashton et al., 2010).

\subsubsection{Characteristics of microplastic abundance distribution in wetland soils and its influencing factors}

The average abundance of microplastics in wetland soil interstitial water in this study area ranged from 563.3 - $6196.7 \mathrm{n} / 500 \mathrm{~g}$, which was significantly higher than the average abundance of microplastics in this area in 2017 (490 - $1170 \mathrm{n} / 500 \mathrm{~g})$ (Deng, 2019). It is worth noting that the proximity of the sampling area to mariculture areas and the relatively intensive production activities are important causes of microplastic accumulation in the region. It has been pointed out that exogenous inputs from human activities have a very significant correlation with the distribution of microplastic contaminants, and the fewer human activities, the lower the level of microplastic pollution (Nor and Obbard, 2014). Besides, as Jinjiang, Fujian Province, is the footwear capital and textile and garment production base in China, a large number of microplastics may remain in industrial production and residential sewage, while the present study area is located at the mouth of the Jinjiang River and the East

Page $12 / 24$ 
China Sea, microplastics carried in the drainage system may be partially intercepted in the mangrove wetland soil, resulting in a high abundance of soil microplastics in the area (Ben-David et al., 2021). Besides, the abundance of soil microplastics in this mangrove restoration wetland study area varied significantly at different planting densities $(p<0.05$, Figure $6 . A)$, and was highest in the $0.5 \times 0.5 \mathrm{~m}$ area. On the one hand, dense vegetation in wetlands can effectively trap microplastics (Sutton et al., 2016), and although plastic or microplastics may be transferred from surface water to seawater in mangrove ecosystems, mangrove vegetation can effectively inhibit this transfer process (Li et al., 2019), thus allowing microplastics to be retained in the wetland soil environment. On the other hand, microplastics can also adhere to mangrove branches or be trapped by other trailing plants in the wetland and enter the soil through rainfall, wind, and other forces (Li et al., 2018).

\subsection{Influence of microplastics (PET) on soil physicochemical properties 4.2.1 Effect of PET on the particle size of wetland soils}

The distribution of soil particle sizes (clay, chalk, and sand) has a very important influence on soil properties, especially on soil texture (Zhang et al., 2016). There were significant differences in the distribution of each soil particle size (clay, silt, and sand) after the addition of exogenous microplastic PET to the wetland bare ground soil and the vegetated area soil. The proportion of clay particles in the wetland soil decreased after PET addition, while the proportion of chalk particles remained stable, but the proportion of sand particles increased. In other words, the proportion of clay particles decreased and the proportion of sand particles increased, which is consistent with the significant negative correlation between clay and sand particles in this study $(p<0.05$, Figure 12). The reason for this phenomenon is that the small size and stickiness of the mucilage particles in the soil particles may cause adhesion when they come into contact with the PET, thus forming large size soil particles (Jeong, 2014), while the PET itself has many voids on its surface (Figure 1.f), which can become a space for small size soil particles to enter. This leads to a decrease in the proportion of clay particles and an increase in the proportion of sand particles in the soil (Wang et al., 2019). Besides, it has been suggested that soils with low clay content and high sand content are not conducive to plant growth, as they can reduce soil water and nutrient retention and fertility on the one hand, and reduce soil respiration on the other (Garcia-Meza et al., 2004; Hall et al., 2010; Nguye and Marschner, 2014). In this study, the proportion of clay particles in bare ground soils did not show a trend very similar to that of soils in vegetated areas, but there was a significant increase in the proportion of sand particles in bare ground soils. On the one hand, the adhesion of bare ground soils is usually lower than that of vegetated soils (Boer and Puigdefábregas, 2010), which does not facilitate the adhesion of small and medium-sized soil particles to form large-sized soil particles, so the proportion of clay particles in bare ground soils does not decrease significantly after PET incubation, but its adhesion can also facilitate its adhesion to PET to form large-sized soil particles such as sand particles. The coefficients of variation (Tables 2 ) reflect whether the distribution of clay, chalk, and sand particles is uniform in bare ground and vegetated soils after PET incubation (Altunkaynak and Gamgam, 2019). Firstly, the CV values of chalk grains were $<10 \%$ for both soils after PET incubation, indicating that the distribution of chalk grains remained relatively stable after the addition of PET. In contrast, the CV values of both clay and sand grains were higher, especially the CV values of sand grains were $>10 \%$, indicating that the distribution of clay and sand grains was not uniform after PET was added again. Besides, the CV values of the vegetated soils were higher than those of the bare ground soils after the addition of PET, indicating that the distribution of each particle size in the vegetated soils was more unstable and fluctuated more than that of the bare ground soils after the PET incubation, which also indicates to a certain extent that the particle size distribution of the vegetated soils is more susceptible to the influence of PET.

\subsubsection{Effect of PET on pH of wetland soil}

Soil pH is an intensity value of soil acidity, representing the active acidity of the soil, which directly affects the state of presence, transformation, and effectiveness of soil nutrients, which in turn affects plant growth and development (Hong et al., 2018). In this study, the soil pH of the wetland bare ground soil and the vegetated area soil after the addition of PET showed little change compared to CK, but still showed an overall decreasing trend, indicating that PET increases soil acidity to some extent. Bandow et al (Bandow et al., 2017) also reported that the presence of microplastics (e.g. HDPE) can reduce soil pH, and they found that HDPE particles reduced soil pH after 6 and 12 weeks of exposure to light and thermal oxidation conditions. Similar to HDPE particles, PET may have altered cation exchange in the soil, which in turn led to changes in soil pH. Janczak et al (Janczak et al., 2018) found that the presence of plastic lowered soil pH and increased its redox sites after 6 months of incubation in soil, and there is some similarity to this study, but the mechanism of change needs to be further investigated. However, changes in soil pH can directly interfere with the diversity and composition of soil microorganisms, thus affecting both the soil microbial community and the inter-rooted microbial community (Boots et al., 2019). Recent studies have shown that the addition of $28 \% \mathrm{w} / \mathrm{w}$ polypropylene microplastics to soil altered the microbial activity and nutrient content of dissolved organic matter as measured by hydrolyzed fluorescein diacetate than when no microplastics were added (Liu et al., 2017). Similarly, De et al (Machado et al., 2018) reported that soil microbial activity responds to the addition of microplastics, depending on the concentration of addition. Microbial activity plays an important role in the decomposition of soil organic matter and the cycling of major nutrients, which are essential for plant growth and root development, and the transformation of functional processes, including microbially driven processes, can also have an impact on this (Yan et al., 2017).

\subsubsection{Effects of PET on soil nitrogen}


Of all essential plant nutrients, nitrogen is the most important factor limiting plant growth and yield, and the ability of soil nitrogen supply can be elucidated by analyzing total soil nitrogen content and morphology (Qi et al., 2021). Besides, soil effective nitrogen exists in the form of nitrogen that can be directly absorbed by plant roots, while ammonium and nitrate nitrogen can be directly absorbed by plant roots and are often collectively referred to as effective nitrogen (Mengel, 1991). In this study, the trends in the total $\mathrm{N}$ content of the wetland bare ground soils after PET addition differed significantly from those of the vegetated areas, and both soils showed a significant decrease in total $\mathrm{N}$ content compared to the CK group (Figure 9. A, B). This is similar to the study by Wang et al (Wang et al., 2016), where the presence of microplastics was able to significantly reduce the soil $\mathrm{N}$ content. Besides, combined with the analysis of soil ammonium nitrogen $\left(\mathrm{NH}_{4}{ }^{+}-\mathrm{N}\right)$ and nitrate-nitrogen $\left(\mathrm{NO}_{3}{ }^{-} \mathrm{N}\right)$, it was found that the overall change of $\mathrm{NH}_{4}{ }^{+}-\mathrm{N}$ content in wetland soils after PET treatment showed a decreasing trend, especially the $\mathrm{NH}_{4}{ }^{+}-\mathrm{N}$ content of soils in vegetated areas significantly decreased by $67.93 \%$ and $79.84 \%$ after $7 \%$ and $28 \%$ PET treatment, respectively, compared with the $\mathrm{CK}\left(\mathrm{p}<0.05\right.$. Table 7). This result is similar to the findings of Chen et al (Chen et al., 2020), which showed that the concentration of $\mathrm{NH}_{4}{ }^{+}-\mathrm{N}$ in the soil was significantly reduced between day 12 and day 15 under the action of microplastics by only $44.3 \%$ and $21.3 \%$ of CK. And it has also been noted that $\mathrm{NH}_{4}{ }^{+}-\mathrm{N}$ concentrations in soils containing HDPE were half that of the sediment without microplastics (Green et al., 2016). For $\mathrm{NO}_{3}-\mathrm{N}$, all wetland soils treated with PET showed a significant increase in NO3-N content compared to the CK group ( $p<0.05$, Table 6). On the one hand, PET can chelate $\mathrm{NH}_{4}{ }^{+}-\mathrm{N}$ by having carbonyl $(=0)$ and hydroxyl groups $(-\mathrm{OH})$ on the surface (Yuan et al., 2020); on the other hand, we found that the concentration of $\mathrm{NO}_{3}{ }^{-} \mathrm{N}$ showed an increasing trend in $\mathrm{M} 1$ and $\mathrm{M} 2$ (Figure 9. F), which indicates that PET can accelerate the soil nitrification process and thus reduce the content of $\mathrm{NH}_{4}{ }^{+}-\mathrm{N}$, which in turn affects the transformation of $\mathrm{N}$ in the soil. MPs have been reported to alter the soil biophysical environment and increase soil porosity, which may increase air flux in the soil and explain the promotion of ammonia oxidation to provide sufficient dissolved oxygen (Machado et al., 2018; Rubol et al., 2013). Furthermore, it has been suggested that the presence of microplastics can alter the availability of substrates for soil denitrification and anaerobic ammonia oxidation processes, which would significantly affect soil $\mathrm{N}$ conversion (Huang et al., 2021).

\subsubsection{Effects of PET on phosphorus and phosphatase in wetland soil}

Although the total phosphorus content of the soil does not directly reflect the phosphorus supply capacity of the soil, if the total phosphorus content of the soil is very low $(<0.4 \mathrm{~g} / \mathrm{kg}$ ), the phosphorus supply may be inadequate (Chi et al., 2011). In this study, the total phosphorus (TP) content of the bare ground soils treated with aM1 and ${ }^{\mathrm{a}} \mathrm{M} 2$ was significantly reduced compared to the ${ }^{\mathrm{a}} \mathrm{CK}(\mathrm{p}<0.05$, Table 7$)$, especially the TP content of the bare ground soils treated with aM2 dropped below $400 \mathrm{mg} / \mathrm{kg}$, which would result in an inadequate phosphorus supply to this soil (Figure 10. A). Although the soil in the vegetated area had a higher overall total phosphorus content (>690 mg/kg), the addition of PET also significantly reduced the total soil phosphorus compared to ${ }^{b} \mathrm{CK}(\mathrm{p}<0.05$, Table 7$)$, indicating that the presence of PET would result in an inadequate phosphorus supply to the soil. The reason for this is the sorption of phosphate to the soil by microplastics (Huang et al., 2019). Soil phosphatase, an enzyme that catalyzes the mineralization of soil organic phosphorus, has a direct impact on the decomposition and conversion of soil organic phosphorus and its biological effectiveness (Yan et al., 2014). Typically, soil enzymes are derived from soil microorganisms, animal and plant roots, and debris decomposition, with soil microorganisms being the main source of soil enzyme formation and accumulation (Weintraub and Schimel, 2005). Enzymes and microorganisms combine to transform organic matter in the soil and play an important role in the biogeochemical cycling of chemical elements and the degradation of pollutants (Sarand; et al., 1998), and soil enzyme activity is susceptible to physical, chemical, and biological factors as well as exogenous contamination (Fernandez et al., 2004). In this study, both bare ground soil and vegetated area soil phosphatase activity after PET addition were significantly different compared to the CK $(p<0.05$, Table 8$)$, especially in the vegetated area soil enzyme activity was significantly lower after ${ }^{\mathrm{b}} \mathrm{M} 1$ and ${ }^{\mathrm{b}} \mathrm{M} 2$ treatment compared to the ${ }^{\mathrm{b}} \mathrm{CK}(\mathrm{p}<0.05, \mathrm{Table} 8)$. Yi et al $(\mathrm{Yi}$ et al., 2021) also found that microplastics reduced soil urease, dehydrogenase, and phosphatase activities. The decrease in phosphatase activity in this study was mainly due to the high PET content ( $7 \%$ and $28 \%$ w/w), however this finding is in contrast to the inhibition of FDAse activity caused by PVC or PE, where the addition of MPs to the soil stimulated urease and phosphatase activity (Machado et al., 2019), a difference that may be due to soil characteristics and the type of MPs (Fei et al., 2020). Besides, it has been suggested that microplastics can alter soil properties by increasing soil permeability and reducing heat uptake, which would affect soil enzyme activity (Carson, 2013).

\section{Conclusion}

This study investigated the distribution of soil microplastics at different planting densities and their effects on the soil properties of mangrove restoration wetlands in the Jinjiang estuary. The conclusions are as follows: The smaller diameter microplastics were easy to accumulate in the wetland soil, and the soil microplastic abundance size was ranked as $0.5 \times 0.5 \mathrm{~m}>1.0 \times 0.5 \mathrm{~m}>1.0 \times 1.0 \mathrm{~m}>$ control area at different planting densities in the restored area. Three microplastics, polyethylene terephthalate (PET), polyethylene (PE), and polypropylene (PP), were identified by Raman spectroscopy as the most prevalent and dominant microplastics in the soils of the region, suggesting that textile and clothing production and laundering of clothing, mariculture, and waste plastic products from human daily life are the main sources of microplastics in the region.SEM images showed that fractures, tears, pits, lamellae, and EDS spectroscopy shows that large amounts of metals are detected on the surface of microplastics, indicating that microplastics are carriers of heavy metals and can be an important source, migration, and exposure pathway for heavy metals. 
In a study of the properties of PET on soil, it was found that PET can influence the distribution of soil particle size due to its adsorptive viscosity. Except for soil $\mathrm{pH}$, all other physicochemical factors changed significantly in response to PET. On the one hand, PET can significantly reduce the content of nitrogen and phosphorus and the activity of soil phosphatase in wetland soils; on the other hand, PET can accelerate the nitrification process in soils, thus reducing the content of ammonium nitrogen, which in turn affects the transformation of nitrogen in soils. The results of the $\mathrm{CV}$ analysis reflect the fact that soils in vegetated areas are more susceptible to the effects of PET than bare ground soils resulting in greater variation in each characteristic.

To more fully investigate the effects of microplastics on soil properties, studies on soil properties using a wider range of microplastics should be considered, and in addition to laboratory experiments, field experiments could be considered to add more practical applications, and the periodicity of the experiments should also be increased. Besides, complex experiments combined with plant and soil animals could be carried out in addition to pure soil characterization studies to obtain more research results.

\section{Declarations}

\section{Acknowledgements}

This work supported by the National Natural Science Foundation of China (No. 20777021), the Natural Science Foundation of Fujian Province of China (No. 2017J01018), Quanzhou City Science \& Technology Program of China (No. 2018Z003), Teaching development and reform project of Huaqiao University (19JF-JXGZ25), New Engineering Demonstration Course Construction Project of Huaqiao University, 2019 (No.22) and Subsidized Project for Postgraduates' Innovative Fund in Scientific Research of Huaqiao University. The Instrumental Analysis Centre of Huaqiao University for analytical characterization is also acknowledged.

\section{References}

1. Altunkaynak B, Gamgam H (2019) Bootstrap confidence intervals for the coefficient of quartile variation. Communications in StatisticsSimulation and Computation 48(7):2138-2146. http://doi.org/10.1080/03610918.2018.1435800

2. Amrutha K, Warrier AK (2020) The first report on the source-to-sink characterization of microplastic pollution from a riverine environment in tropical India. Sci Total Environ 739:140377. http://doi.org/10.1016/j.scitotenv.2020.140377

3. Ashton K, Holmes L, Turner A (2010) Association of metals with plastic production pellets in the marine environment. Mar Pollut Bull 60(11):2050-2055. http://doi.org/10.1016/j.marpolbul.2010.07.014

4. Bandow N, Will V, Wachtendorf V, Simon F-G (2017) Contaminant release from aged microplastic. Environ Chem 14(6):394-405. http://doi.org/10.1071/en17064

5. Ben-David EA, Habibi M, Haddad E, Hasanin M, Angel DL, Booth AM, Sabbah I (2021) Microplastic distributions in a domestic wastewater treatment plant: Removal efficiency, seasonal variation and influence of sampling technique. Sci Total Environ 752:141880-141880. http://doi.org/10.1016/j.scitotenv.2020.141880

6. Boer M, Puigdefábregas J (2010) Effects of spatially structured vegetation patterns on hillslope erosion in a semiarid Mediterranean environment: a simulation study. Earth Surface Processes \& Landforms 30(2):149-167

7. Boots B, Russell CW, Green DS (2019) Effects of Microplastics in Soil Ecosystems: Above and Below Ground. Environ Sci Technol 53(19):11496-11506. http://doi.org/10.1021/acs.est.9b03304

8. Carson HS (2013) The incidence of plastic ingestion by fishes: From the prey's perspective. Mar Pollut Bull 74(1):170-174. http://doi.org/10.1016/j.marpolbul.2013.07.008

9. Cesa FS, Turra A, Baruque-Ramos J (2017) Synthetic fibers as microplastics in the marine environment: A review from textile perspective with a focus on domestic washings. Sci Total Environ 598(15):1116-1129

10. Chamas A, Moon H, Zheng JJ, Qiu Y, Tabassum T, Jang JH, Abu-Omar M, Scott SL, Suh S (2020) Degradation Rates of Plastics in the Environment. ACS Sustain Chem Eng 8(9):3494-3511. http://doi.org/10.1021/acssuschemeng.9b06635

11. Chen HQ, Wang YH, Sun X, Peng YK, Xiao L (2020) Mixing effect of polylactic acid microplastic and straw residue on soil property and ecological function. Chemosphere 243:1-9. http://doi.org/10.1016/j.chemosphere.2019.125271

12. Chi GY, Chen X, Shi Y (2011) Effects of Land Use Type on the Profile Distributions of Soil Amorphous Iron and Total Phosphorus. Adv Sci Lett 4(1):156-158. http://doi.org/10.1166/asl.2011.1175

13. Cincinelli A, Scopetani C, Chelazzi D, Lombardini E, Martellini T, Katsoyiannis A, Fossi MC, Corsolini S (2017) Microplastic in the surface waters of the Ross Sea (Antarctica): Occurrence, distribution and characterization by FTIR. Chemosphere 175:391-400

14. Deng J (2019) Effects of mangrove wetland restoration on the heavy metals and microplastics of soils in Jinjiang Estuaty. Huanqiao University, Xiamen 
15. Deng J, Guo PY, Zhang XY, Su HT, Li YQ (2020) Microplastics and accumulated heavy metals in restored mangrove wetland surface sediments at Jinjiang Estuary (Fujian, China). Mar Pollut Bull 159:111482. http://doi.org/10.1016/j.marpolbul.2020.111482

16. Dong MT, Zhang QQ, Xing XL, Chen W, She ZB, Luo ZJ (2020) Raman spectra and surface changes of microplastics weathered under natural environments. Sci Total Environ 739:1-9. http://doi.org/10.1016/j.scitotenv.2020.139990

17. Edo C, Pleiter MG, Belda MT, Ortega-Ojeda FE, Rosal R (2020) Microplastics in sediments of artificially recharged lagoons: Case study in a Biosphere Reserve. Sci Total Environ 729:1-11

18. Fei YF, Huang SY, Zhang HB, Tong YZ, Wen DS, Xia XY, Wang H, Luo YM, Barcelo D (2020) Response of soil enzyme activities and bacterial communities to the accumulation of microplastics in an acid cropped soil. Sci Total Environ 707:1-11. http://doi.org/10.1016/j.scitotenv.2019.135634

19. Fernandez C, Alonso C, Babin MM, Pro J, Carbonell G, Tarazona JV (2004) Ecotoxicological assessment of doxycycline in aged pig manure using multispecies soil systems. Sci Total Environ 323(1-3):63-69. http://doi.org/10.1016/j.scitotenv.2003.10.015

20. Frere L, Paul-Pont I, Moreau J, Soudant P, Lambert C, Huvet A, Rinnert E (2016) A semi-automated Raman micro-spectroscopy method for morphological and chemical characterizations of microplastic litter. Mar Pollut Bull 113(1-2):461-468. http://doi.org/10.1016/j.marpolbul.2016.10.051

21. Garces-Ordonez O, Castillo-Olaya VA, Granados-Briceno AF, Blandon Garcia LM, Diaz E, L.F (2019) Marine litter and microplastic pollution on mangrove soils of the Cienaga Grande de Santa Marta, Colombian Caribbean. Mar Pollut Bull 145:455-462

22. Garcia-Meza JV, Ramos E, Carrillo-Chavez A, Duran-de-Bazua C (2004) Mineralogical and chemical characterization of historical mine tailings from the Valenciana Mine, Guanajuato, Mexico: Environmental implications. Bull Environ Contam Toxicol 72(1):170-177. http://doi.org/10.1007/s00128-003-0256-1

23. Green DS, Boots B, Sigwart J, Jiang S, Rocha C (2016) Effects of conventional and biodegradable microplastics on a marine ecosystem engineer (Arenicola marina) and sediment nutrient cycling. Environ Pollut 208:426-434. http://doi.org/10.1016/j.envpol.2015.10.010

24. Hall DJM, Jones HR, Crabtree WL, Daniels TL (2010) Claying and deep ripping can increase crop yields and profits on water repellent sands with marginal fertility in southern Western Australia. Soil Research 48(2):178-187

25. Han M, Niu XR, Tang M, Zhang BT, Wang GQ, Yue WF, Kong XL, Zhu JQ (2020) Distribution of microplastics in surface water of the lower Yellow River near estuary. Sci Total Environ 707:1-9. http://doi.org/10.1016/j.scitotenv.2019.135601

26. Hong SB, Piao SL, Chen AP, Liu YW, Liu LL, Peng SS, Sardans J, Sun Y, Penuelas J, Zeng H (2018) Afforestation neutralizes soil pH. Nat Commun 9:1-7. http://doi.org/10.1038/s41467-018-02970-1

27. Hossain MR, Jiang M, Wei QH, Leff LG (2018) Microplastic surface properties affect bacterial colonization in freshwater. J Basic Microbiol 59(1):54-61

28. Hu R, Wang XP, Xu JS, Zhang YF, Pan YX, Su X (2020) The mechanism of soil nitrogen transformation under different biocrusts to warming and reduced precipitation: From microbial functional genes to enzyme activity. Sci Total Environ 722:1-10

29. Huang XQ, Wu WF, Xia Y, Li WB, Gong YY, Li ZJ (2019) Alkali resistant nanocomposite gel beads as renewable adsorbents for water phosphate recovery. Sci Total Environ 685:10-18. http://doi.org/10.1016/j.scitotenv.2019.05.296

30. Huang Y, Li W, Gao J, Wang F, Yang W, Han L, Lin D, Min B, Zhi Y, Grieger K, Yao J (2021) Effect of microplastics on ecosystem functioning: Microbial nitrogen removal mediated by benthic invertebrates. Sci Total Environ 754:1-9. http://doi.org/10.1016/j.scitotenv.2020.142133

31. Hueffer T, Metzelder F, Sigmund G, Slawek S, Schmidt TC, Hofmann T (2019) Polyethylene microplastics influence the transport of organic contaminants in soil. Sci Total Environ 657:242-247

32. Janczak K, Hrynkiewicz K, Znajewska Z, Dabrowska G (2018) Use of rhizosphere microorganisms in the biodegradation of PLA and PET polymers in compost soil. Int Biodeterior Biodegrad 130:65-75. http://doi.org/10.1016/j.ibiod.2018.03.017

33. Jeong SW (2014) The effect of grain size on the viscosity and yield stress of fine-grained sediments. J Mt Sci 11(1):31-40. http://doi.org/10.1007/s11629-013-2661-1

34. Jiang CB, Yin LS, Li ZW, Wen XF, Luo X, Hu SP, Yang HY, Long YN, Deng B, Huang LZ, Liu YZ (2019) Microplastic pollution in the rivers of the Tibet Plateau. Environ Pollut 249:91-98

35. Karstens S, Buczko U, Glatzel S (2015) Phosphorus storage and mobilization in coastal Phragmites wetlands: Influence of local-scale hydrodynamics. Estuar Coast Shelf Sci 164:124-133. http://doi.org/10.1016/j.ecss.2015.07.014

36. Langan C, Farmer J, Rivington M, Smith JU (2018) Tropical wetland ecosystem service assessments in East Africa; A review of approaches and challenges. Environ Model Softw 102:260-273. http://doi.org/10.1016/j.envsoft.2018.01.022

37. Li J, Zhang H, Zhang KN, Yang Rj, Li RZ, Li YF (2018) Characterization, source, and retention of microplastic in sandy beaches and mangrove wetlands of the Qinzhou Bay, China. Mar Pollut Bull 136:401-406. http://doi.org/10.1016/j.marpolbul.2018.09.025

38. Li RL, Zhang LL, Xue BM, Wang YH (2019) Abundance and characteristics of microplastics in the mangrove sediment of the semi-enclosed Maowei Sea of the south China sea: New implications for location, rhizosphere, and sediment compositions. Environ Pollut 244:685-692. 
http://doi.org/10.1016/j.envpol.2018.10.089

39. Liu HF, Yang XM, Liang CT, Li YZ, Qiao LL, Ai ZM, Xue S, Liu GB (2019a) Interactive effects of microplastics and glyphosate on the dynamics of soil dissolved organic matter in a Chinese loess soil. CATENA 182:1-11. http://doi.org/10.1016/j.catena.2019.104177

40. Liu HF, Yang XM, Liu GB, Liang CT, Xue S, Chen H, Ritsema CJ, Geissen V (2017) Response of soil dissolved organic matter to microplastic addition in Chinese loess soil. Chemosphere 185:907-917. http://doi.org/10.1016/j.chemosphere.2017.07.064

41. Liu HY, Tang L, Liu Y, Zeng GM, Lu Y, Wang JJ, Yu JF, Yu ML (2019b) Wetland-a hub for microplastic transmission in the global ecosystem. Resources Conservation and Recycling 142:153-154. http://doi.org/10.1016/j.resconrec.2018.11.028

42. Liu XM, Shi HH, Xie B, Dionysiou DD, Zhao YP (2019c) Microplastics as Both a Sink and a Source of Bisphenol A in the Marine Environment. Environ Sci Technol 53(17):10188-10196

43. Lwanga EH, Gertsen H, Gooren H, Peters P, Salanki T, van der Ploeg M, Besseling E, Koelmans AA, Geissen V (2016) Microplastics in the Terrestrial Ecosystem: Implications for Lumbricus terrestris (Oligochaeta, Lumbricidae). Environ Sci Technol 50(5):2685-2691. http://doi.org/10.1021/acs.est.5b05478

44. Machado AAD, Lau CW, Kloas W, Bergmann J, Bacheher JB, Faltin E, Becker R, Gorlich AS, Rillig MC (2019) Microplastics Can Change Soil Properties and Affect Plant Performance. Environ Sci Technol 53(10):6044-6052. http://doi.org/10.1021/acs.est.9b01339

45. Machado AAdS, Lau CW, Till J, Kloas W, Lehmann A, Becker R, Rillig MC (2018) Impacts of Microplastics on the Soil Biophysical Environment. Environ Sci Technol 52(17):9656-9665. http://doi.org/10.1021/acs.est.8b02212

46. Mehdinia A, Dehbandi R, Hamzehpour A, Rahnama R (2020) Identification of microplastics in the sediments of southern coasts of the Caspian Sea, north of Iran. Environ Pollut 258:10. http://doi.org/10.1016/j.envpol.2019.113738

47. Mengel K (1991) Available nitrogen in soils and its determination by the 'N-Min' method and by electroultrafiltration (EUF). Fertil Res 28(3):251-262

48. Naji A, Nuri M, Amiri P, Niyogi S (2019) Small microplastic particles (S-MPPs) in sediments of mangrove ecosystem on the northern coast of the Persian Gulf. Mar Pollut Bull 146:305-311

49. Nguye TT, Marschner P (2014) Respiration in mixes of sandy and clay soils: influence of clay type and addition rate. Journal of soil science and plant nutrition 14(4):881-887

50. Nor NHM, Obbard JP (2014) Microplastics in Singapore's coastal mangrove ecosystems. Mar Pollut Bull 79(1-2):278-283. http://doi.org/10.1016/j.marpolbul.2013.11.025

51. Peng GY, Zhu BS, Yang DQ, Su L, Shi HH, Li DJ (2017) Microplastics in sediments of the Changjiang Estuary, China. Environ Pollut 225:283290. http://doi.org/10.1016/j.envpol.2016.12.064

52. Qi Q, Zhang DJ, Zhang MY, Tong SZ, Wang WH, An Y (2021) Spatial distribution of soil organic carbon and total nitrogen in disturbed Carex tussock wetland. Ecol Indic 120:1-8. http://doi.org/10.1016/j.ecolind.2020.106930

53. Qi YL, Ossowicki A, Yang XM, Lwanga EH, Dini-Andreote F, Geissen V, Garbeva P (2020) Effects of plastic mulch film residues on wheat rhizosphere and soil properties. J Hazard Mater 387:1-11

54. Qin YM, Wang ZC, Li WP, Chang X, Yang JL, Yang F (2020) Microplastics in the sediment of Lake Ulansuhai of Yellow River Basin, China. Water Environ Res 92(6):829-839. http://doi.org/10.1002/wer.1275

55. Rillig MC, Ingraffia R, Machado A (2017) Microplastic Incorporation into Soil in Agroecosystems. Front. Plant Sci 8:1-7

56. Rubol S, Manzoni S, Bellin A, Porporato A (2013) Modeling soil moisture and oxygen effects on soil biogeochemical cycles including dissimilatory nitrate reduction to ammonium (DNRA). Adv Water Resour 62:106-124. http://doi.org/10.1016/j.advwatres.2013.09.016

57. Sarand; I, Timonen; S, Nurmiaho-Lassila; E-L, Koivula; T, Haahtela; K, Romantschuk M, Sen R (1998) Microbial biofilms and catabolic plasmid harbouring degradative fluorescent pseudomonads in Scots pine mycorrhizospheres developed on petroleum contaminated soil. FEMS Microbiol Ecol 27(2):115-126

58. Sutton R, Mason SA, Stanek SK, Willis-Norton E, Wren IF, Box C (2016) Microplastic contamination in the San Francisco Bay, California, USA. Mar Pollut Bull 109(1):230-235. http://doi.org/10.1016/j.marpolbul.2016.05.077

59. Tan XL, Xu B, Cai LQ, Wang JD, Peng JP (2019) Occurrence and organic contaminant-carrier effect of microplastics in surface water from the Feilaixia Reservoir in the Beijiang River, China. Chemosphere 1-11. http://doi.org/10.1016/j.chemosphere.2019.01.022

60. Veerasingam S, Saha M, Suneel V, Vethamony P, Rodrigues AC, Bhattacharyya S, Naik BG (2016) Characteristics, seasonal distribution and surface degradation features of microplastic pellets along the Goa coast, India. Chemosphere 159:496-505

61. Wang J, Lv SH, Zhang MY, Chen GC, Zhu TB, Zhang S, Teng Y, Christie P, Luo YM (2016) Effects of plastic film residues on occurrence of phthalates and microbial activity in soils. Chemosphere 151:171-177. http://doi.org/10.1016/j.chemosphere.2016.02.076

62. Wang JD, Peng JP, Tan Z, Gao YF, Zhan ZW, Chen QQ, Cai LQ (2017) Microplastics in the surface sediments from the Beijiang River littoral zone: Composition, abundance, surface textures and interaction with heavy metals. Chemosphere 171:248-258.

http://doi.org/10.1016/j.chemosphere.2016.12.074

Page $17 / 24$ 
63. Wang Y, Zou XQ, Peng C, Qiao SQ, Kornkanitnan N (2020) Occurrence and distribution of microplastics in surface sediments from the Gulf of Thailand. Mar Pollut Bull 152:1-9

64. Wang YJ, Chen SC, Guang SS, Wang Y, Zhang XM, Chen WX (2019) Continuous post-polycondensation of high-viscosity poly(ethylene terephthalate) in the molten state. J Appl Polym Sci 136(19):1-12. http://doi.org/10.1002/app.47484

65. Weintraub MN, Schimel JP (2005) The seasonal dynamics of amino acids and other nutrients in Alaskan Arctic tundra soils. Biogeochemistry 73(2):359-380. http://doi.org/10.1007/s10533-004-0363-z

66. Wong JKH, Lee KK, Tang KHD, Yap PS (2020) Microplastics in the freshwater and terrestrial environments: Prevalence, fates, impacts and sustainable solutions. Sci Total Environ 719:1-15

67. Yan M, Yu L, Zhang L, Guo Y, Dai K, Chen Y (2014) Phosphatase activity and culture conditions of the yeast Candida mycoderma sp and analysis of organic phosphorus hydrolysis ability. J Environ Sci 26(11):2315-2321. http://doi.org/10.1016/j.jes.2014.09.008

68. Yan Y, Kuramae EE, de Hollander M, Klinkhamer PGL, van Veen JA (2017) Functional traits dominate the diversity-related selection of bacterial communities in the rhizosphere. ISME J 11(1):56-66. http://doi.org/10.1038/ismej.2016.108

69. Yao WM, Di D, Wang ZF, Liao ZL, Huang H, Mei K, Dahlgren RA, Zhang MH, Shang X (2019) Micro- and macroplastic accumulation in a newly formed Spartina alterniflora colonized estuarine saltmarsh in southeast China. Mar Pollut Bull 149:1-10. http://doi.org/10.1016/j.marpolbul.2019.110636

70. Yi M, Zhou S, Zhang L, Ding S (2021) The effects of three different microplastics on enzyme activities and microbial communities in soil. Water Environ Res 93(1):24-32. http://doi.org/10.1002/wer.1327

71. Yuan XZ, Li SJ, Jeon SB, Deng S, Zhao L, Lee KB (2020) Valorization of waste polyethylene terephthalate plastic into N-doped microporous carbon for CO2 capture through a one-pot synthesis. J Hazard Mater 399:1-10. http://doi.org/10.1016/j.jhazmat.2020.123010

72. Zhang GS, Zhang FX, Li XT (2019) Effects of polyester microfibers on soil physical properties: Perception from a field and a pot experiment. Sci Total Environ 670:1-7. http://doi.org/10.1016/j.scitotenv.2019.03.149

73. Zhang JY, Gu PF, Li LY, Zong LY, Zhao WJ (2016) Changes of soil particle size fraction along a chronosequence in sandy desertified land: a fundamental process for ecosystem succession and ecological restoration. J Soils Sediments 16(12):2651-2656. http://doi.org/10.1007/s11368-016-1454-x

74. Zhou Q, Zhang HB, Fu CC, Zhou Y, Luo YM (2018) The distribution and morphology of microplastics in coastal soils adjacent to the Bohai Sea and the Yellow Sea. Geoderma 322:201-208

\section{Figures}

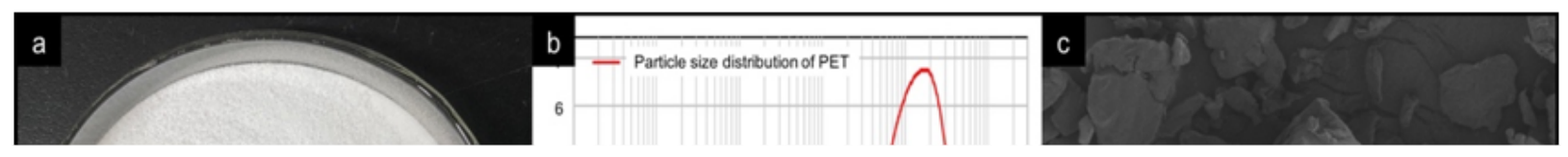

Figure 1 

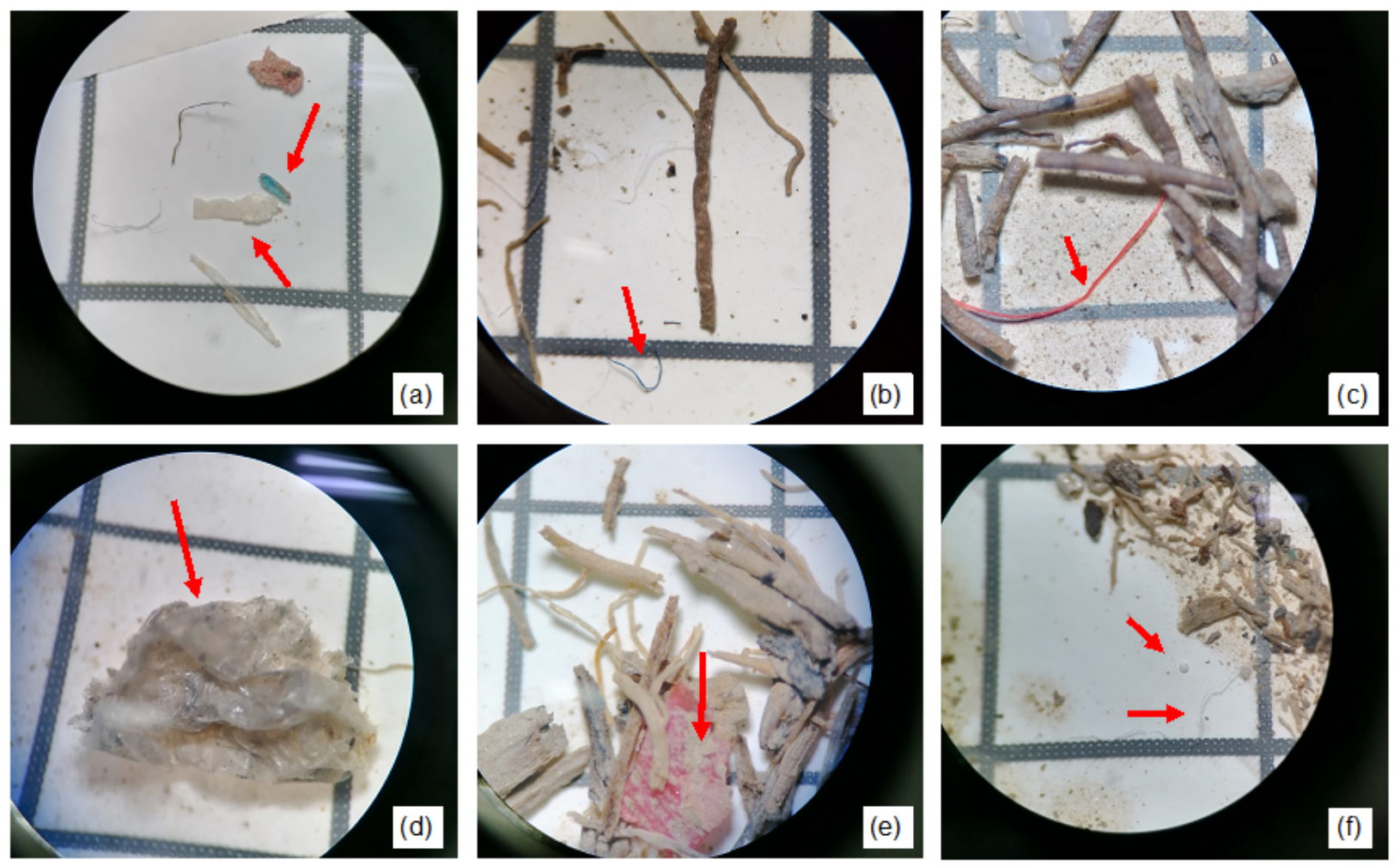

Figure 2

Light microscope images of different types of microplastics.
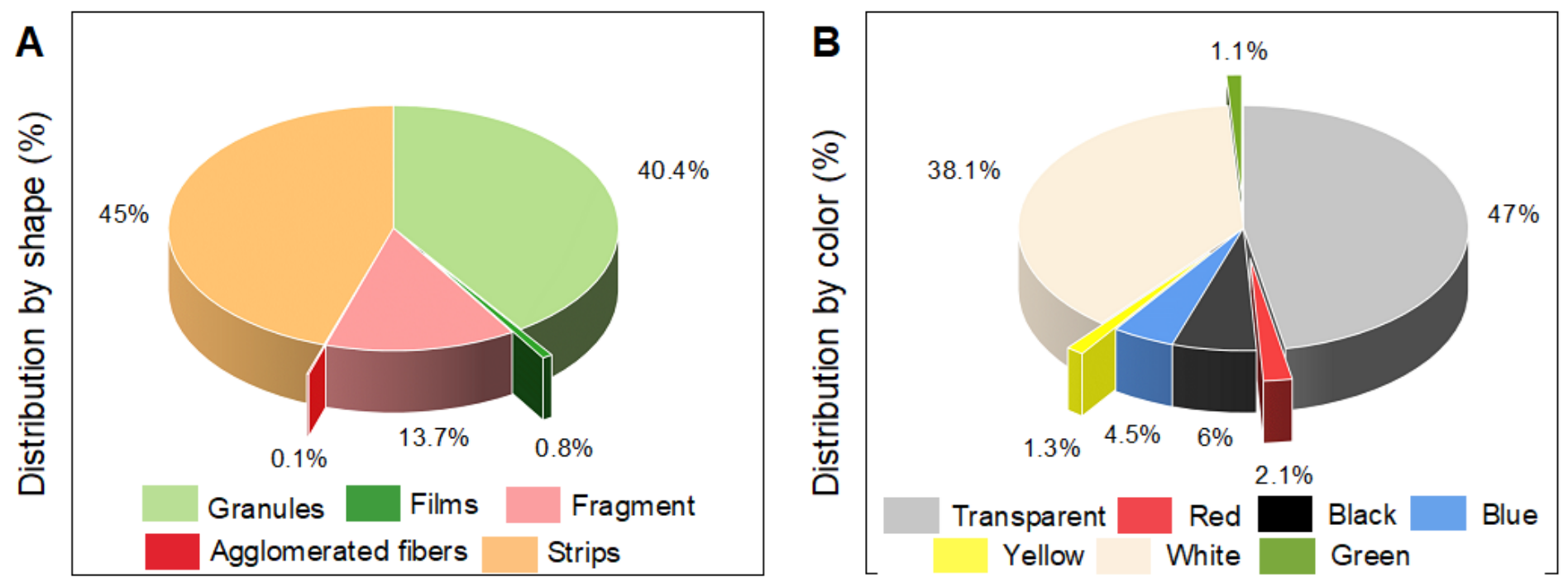

Figure 3

Morphological characteristics of soil microplastics 


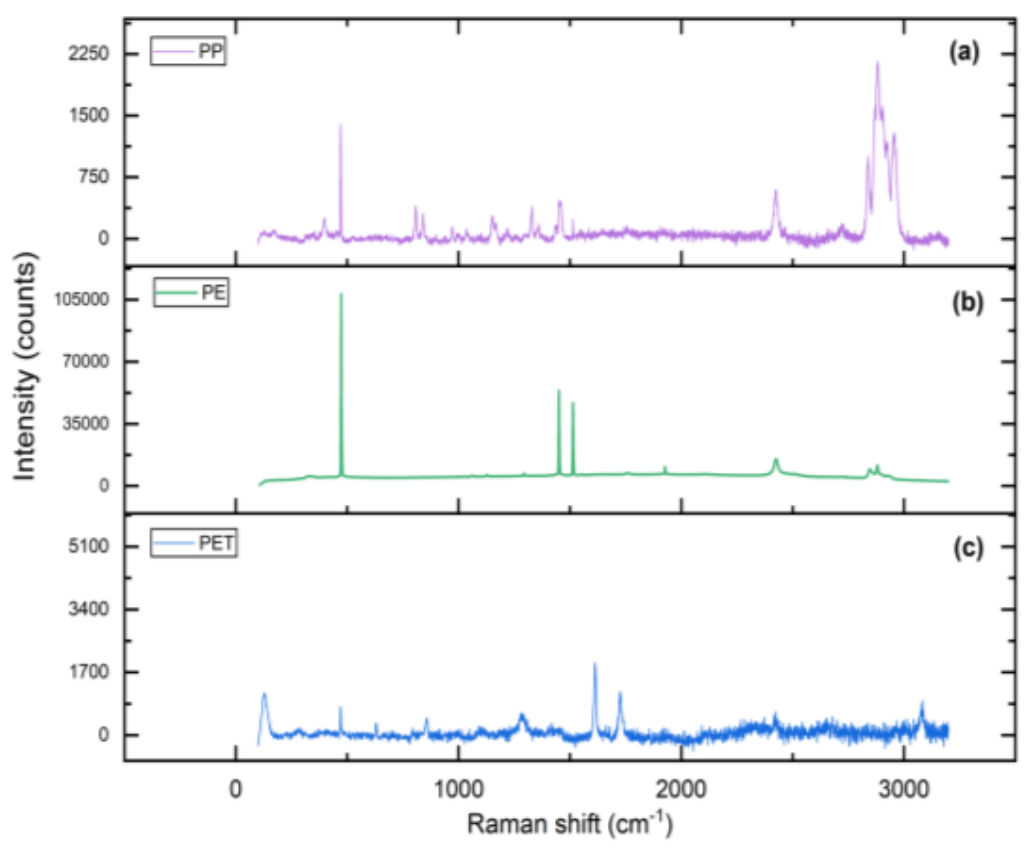

Figure 4

Raman spectra of typical microplastics from soil samples.

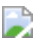

Figure 5

SEM images of microplastic films ( $a, b)$, transparent fibers $(d, e)$, white granular $(g, h)$ and lumps $(j, k)$, and EDS spectra of surface elements of microplastics $(c, f, I, l)$
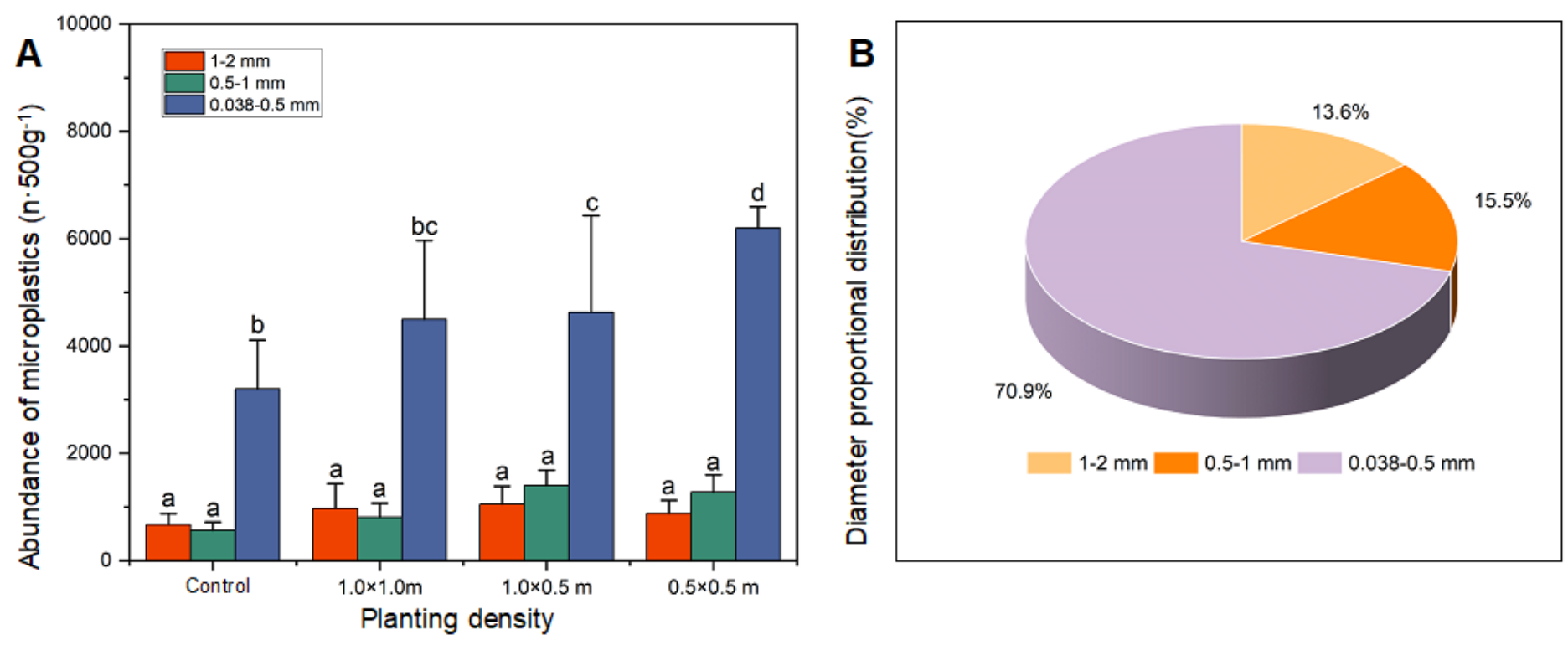

Figure 6

Distribution characteristics of soil microplastics under different planting densities in mangrove restoration wetlands. 
(A. Difference analysis of soil microplastics abundance distribution (different lowercase letters (a/b/c) indicated significant difference in soil microplastics distribution under different planting densities, $\mathrm{p}<0.05)$; B. Proportional distribution of soil microplastics with different diameters)

\section{Figure 7}

Changes in the proportions of clay, silt and sand after the addition of PET.
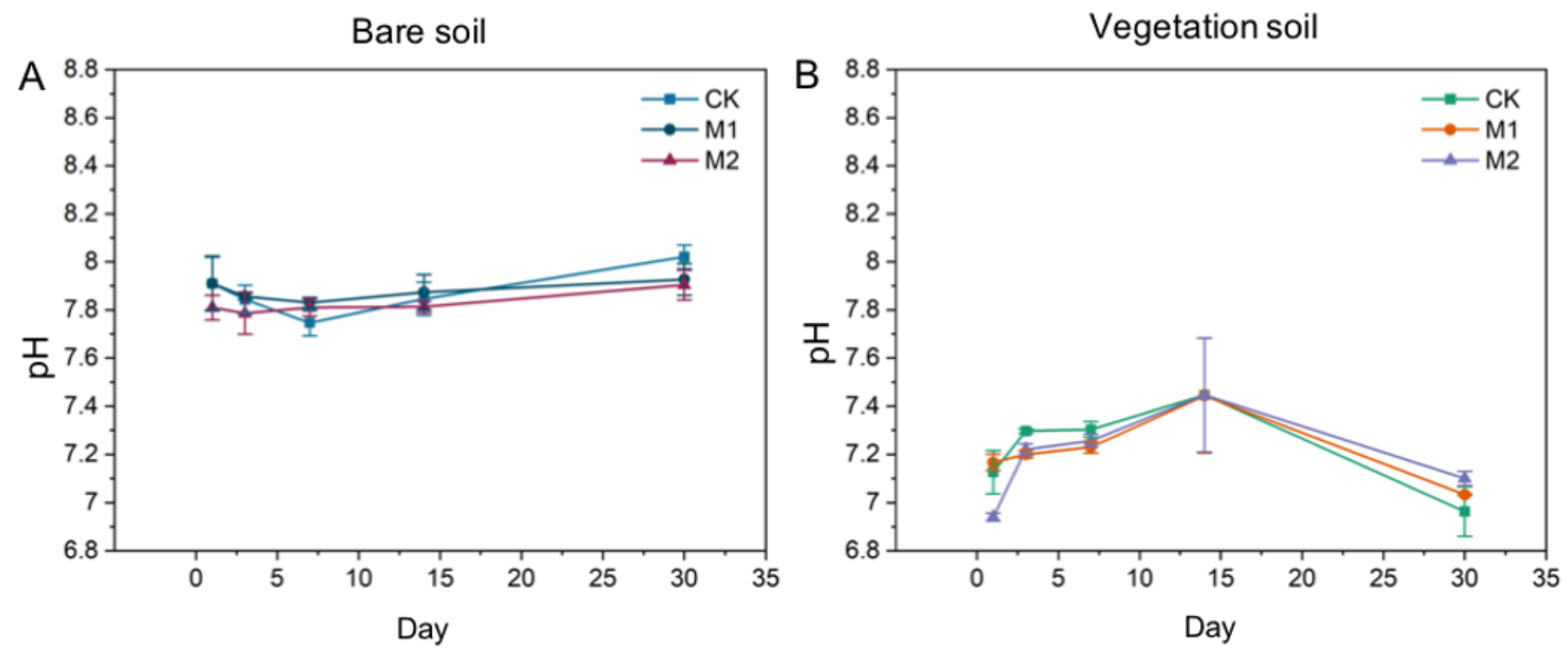

CK: 0\% PET; M1: 7\% PET; M2: 28\% PET

\section{Figure 8}

Changes in $\mathrm{pH}$ of wetland soil after PET addition. 

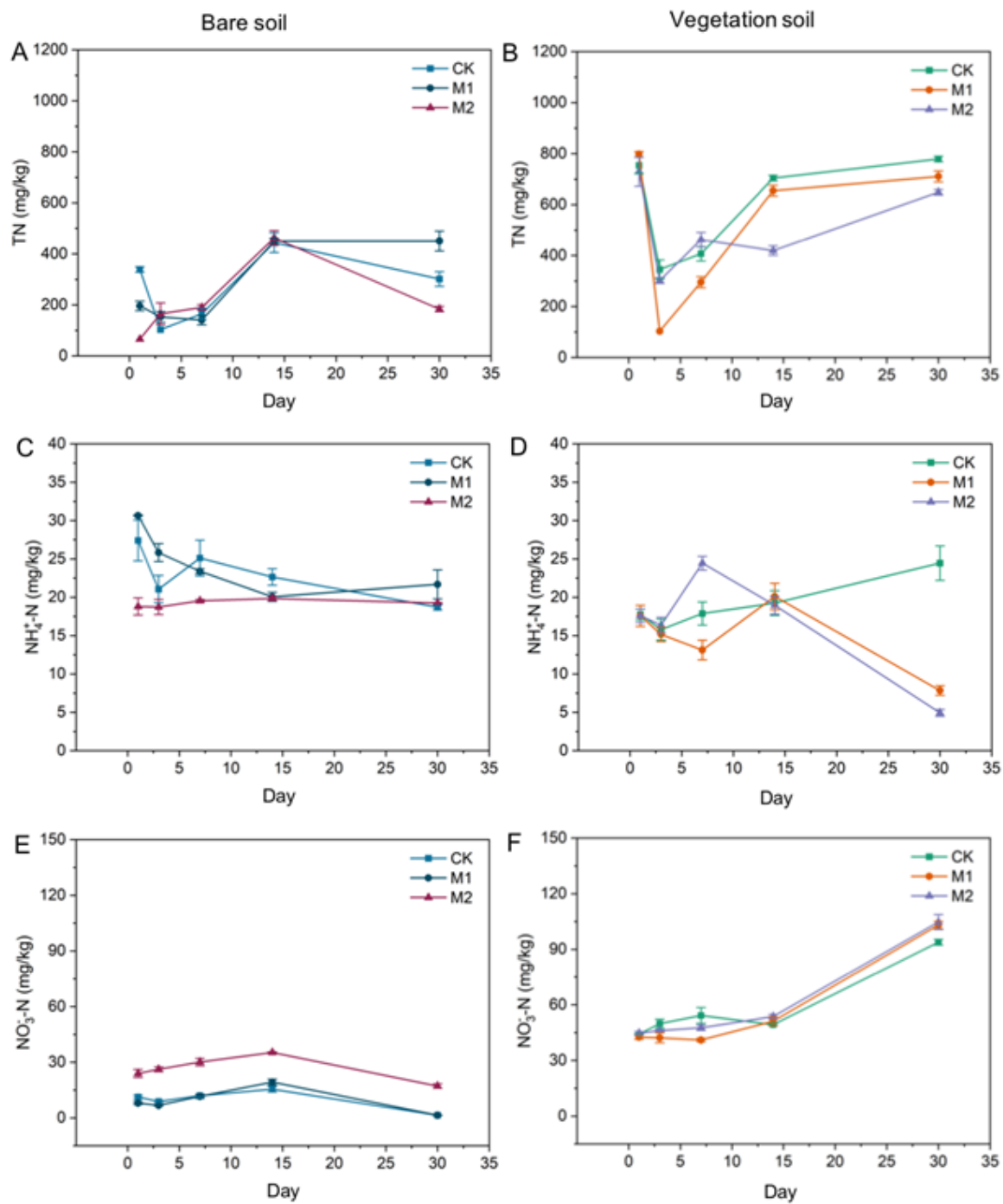

CK: 0\% PET; M1: 7\% PET; M2: 28\% PET

Figure 9

Change characteristics of total nitrogen, ammonium nitrogen and nitrate nitrogen in wetland soil after adding PET culture. 
Bare soil

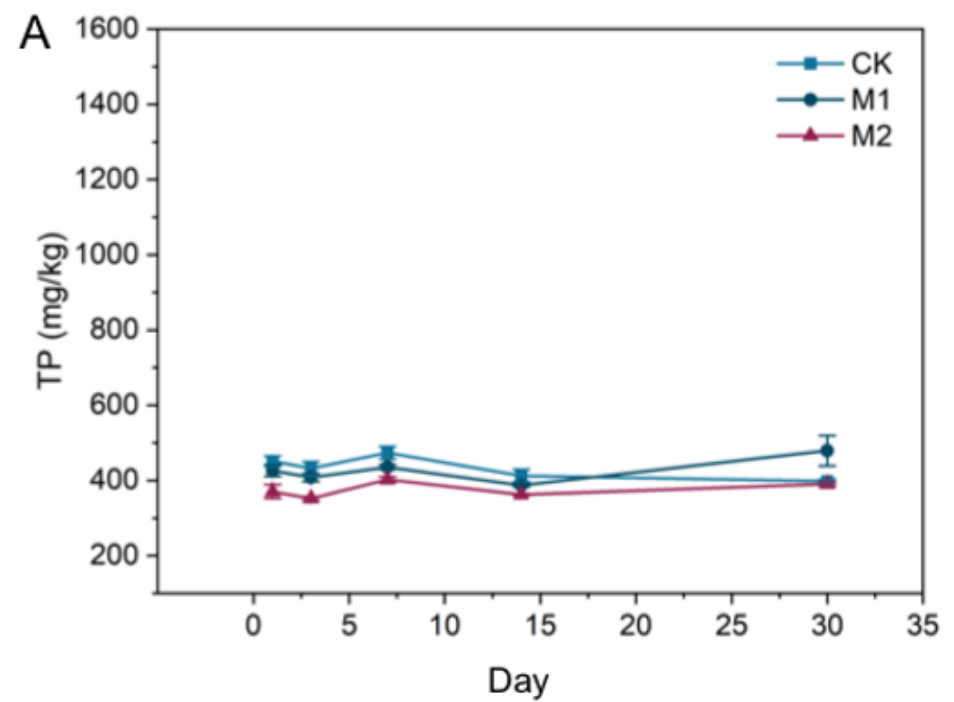

CK: 0\% PET; M1: 7\% PET; M2: 28\% PET
Vegetation soil

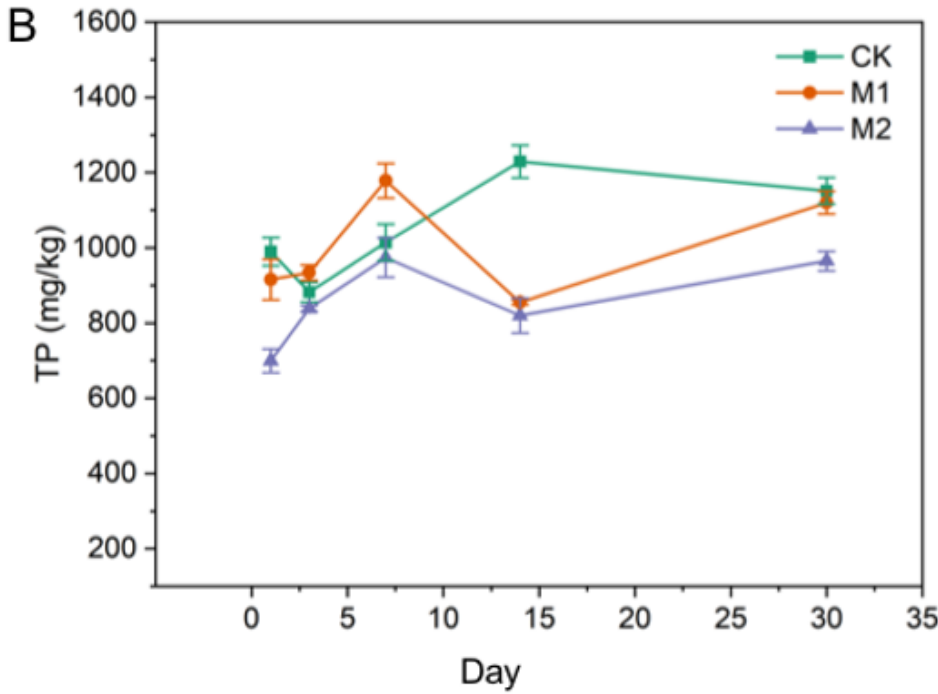

\section{Figure 10}

Change characteristics of total phosphorus in wetland soil after adding PET.
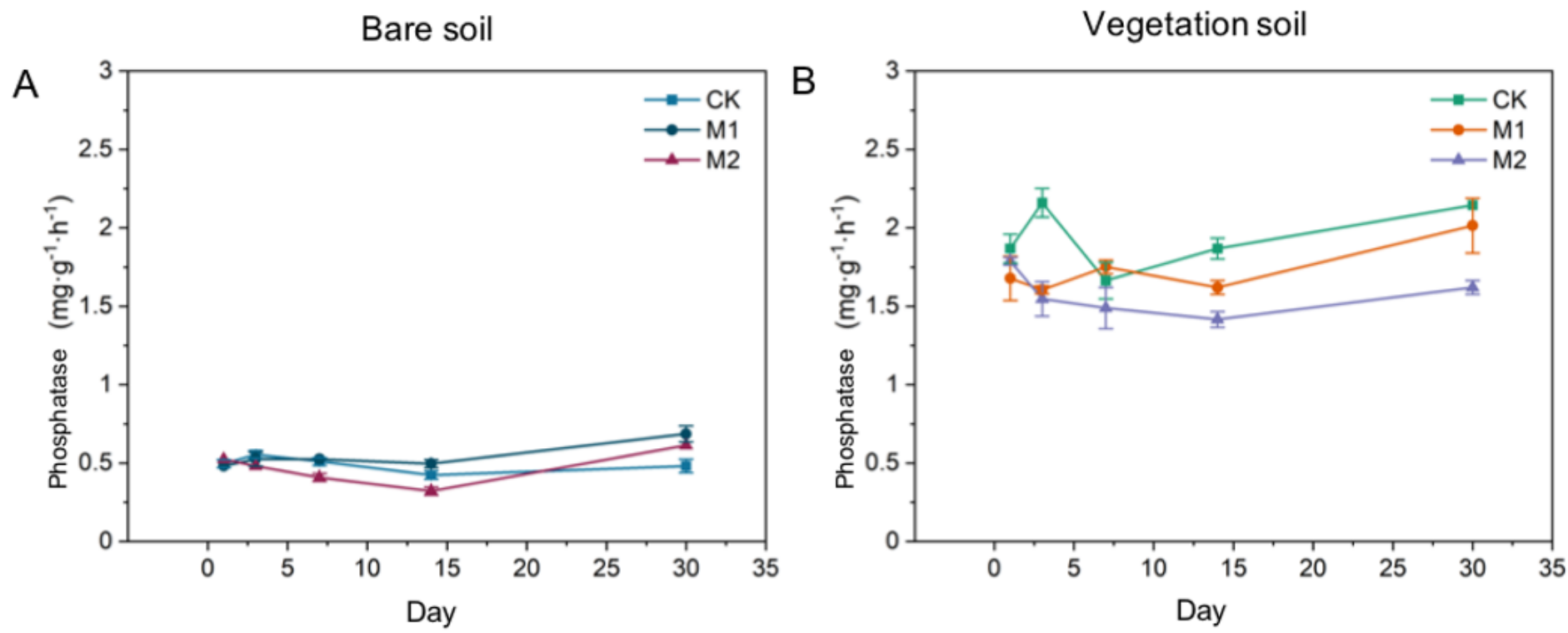

CK: 0\% PET; M1: 7\% PET; M2: 28\% PET

\section{Figure 11}

Change characteristics of phosphatase in wetland soil after adding PET

\section{Figure 12}

Correlation coefficient matrix heat map between soil properties. 


\section{Supplementary Files}

This is a list of supplementary files associated with this preprint. Click to download.

- GraphicalAbstract.docx 